\title{
CHINESE PRIVATIZATION: BETWEEN PLAN AND MARKET
}

\author{
LAN CAO*
}

\section{INTRODUCTION}

Since 1978, when China adopted its open-door policy and allowed its economy to be exposed to the international market, it has adhered to what Deng Xiaoping called "socialism with Chinese characteristics." produced an economy with one of the most rapid growth rates in the world by steadfastly embarking on a developmental strategy of gradual, market-oriented measures while simultaneously remaining nominally socialistic. As I discuss in this article, this strategy of reform-the mere adoption of a market economy while retaining a socialist ownership base-should similarly be characterized as "privatization with Chinese characteristics," even though it departs markedly from the more orthodox strategy most commonly associated with the term "privatization," at least as that term has been conventionally understood in the context of emerging market or transitional economies.

The Russian experience of privatization, for example, represents the more dominant and more favored approach to privatization-certainly from the point of view of the West and its advisers - and is characterized by immediate privatization of the state sector, including the swift and unequivocal transfer of assets from the publicly owned state enterprises to private hands. On the other hand, "privatization with Chinese characteristics" emphasizes not the immediate privatization of the state sector but rather the retention of the state sector with the

Copyright (C) 2001 by Lan Cao

This article is also available at http://www.law.duke.edu/journals/63LCPCao.

* Professor of Law, College of William and Mary Marshall-Wythe School of Law. At the time the article was written, the author was Professor of Law at Brooklyn Law School.

A version of this article was presented at the Public Perspectives on Privatization conference held in Geneva and sponsored by Duke University School of Law, University of Alberta School of Law, and University of Geneva School of Law. I also presented the article at a faculty workshop at the College of William \& Mary Marshall-Wythe School of Law. Thanks to all the participants and colleagues who offered their comments, particularly Professors Andrzej Rapaczynski, Alan Meese, and Inga Markovits. I would also like to acknowledge the invaluable research assistance provided by Whitney Walters and Anya Sobodinska. The article was supported by a summer research stipend granted by Dean Joan G. Wexler and Brooklyn Law School.

1. Deng Xiaoping coined this term in a statement about China's attempts to deal with its exploding population growth: "[T]he problem of China is its excessive population ... [O [O]nly a socialist system can solve this problem .... The socialism we are talking about is one with Chinese characteristics." China Can Only Go the Socialist Road, PEOPLE'S DAILY (Overseas ed.), June 24, 1989, at 1.

2. Matthew Bersani, Privatization and the Creation of Stock Companies in China, 3 Colum. Bus. L. REV. 301, 302 (1993). 
concomitant creation of a parallel non-state sector designed to supplement the state sector and to serve as a social "shock absorber" in the event that the state sector itself is to be eventually "privatized"-or as Chinese officials prefer it, "corporatized" or "securitized." "In this article, I use the term "privatization" to describe China's current stage of ownership reform, even though, as I also suggest in Part IV, the Chinese strategy has not been to hand control and equity over to private holders, but, ironically, to bring private savings into statecontrolled shareholding enterprises. The distinction between "privatization" and "corporatization" or "securitization" rests on the terms' ideological significance to Chinese officials, who view "corporatization," the conversion of a state-owned enterprise into a shareholding company, or "securitization," the subsequent sale of such shares on a securities market, as ideologically compatible with "socialism with Chinese characteristics." On the other hand, "privatization"-stemming from the word "private" and identified with the institution of private ownership without necessarily ensuring the preservation of the state as the agent of the "entire people" in the social ownership of the means of production ${ }^{4}$-is considered to be anathema from an ideological standpoint to the state's official adherence to socialism. ${ }^{5}$

Because China has been ideologically circumscribed by "market socialism"-market-based but only palatable to and compatible with socialism-it has had to opt for a form of privatization that allowed the reformers to argue for market-oriented reform while promising that the state sector itself will be insulated from market encroachments. Despite its blatantly ideological roots, the Chinese path nonetheless should be examined for its arguably legitimate economic and theoretical underpinnings-for example, whether there are valid economic reasons for a strategy that favors retention of the state sector and the concomitant creation of a non-state sector, and whether state-sector privatization, when it is in fact implemented, would be more effective after a full-fledged non-state sector has been created because then the transfer of ownership from state to private hands would be taking place in the context of an already marketized framework. These types of questions will have considerable policy ramifications as more and more countries search for an exit from an economic system based on full public ownership of the means of production and compulsory state economic planning. ${ }^{6}$

3. Even as China introduced a shareholding system, which allowed its state enterprises to be converted into shareholding companies, and even as it instituted securities exchanges in Shanghai and Shenzhen in 1990 and 1991 respectively, the official policy remained one that opposes "privatization" and favors "securitization." See David Blumental, "Reform" or "Opening"? Reform of China's StateOwned Enterprises and WTO Accession-The Dilemma of Applying Gatt to Marketizing Economies, 16 UCLA PAC. BASIN L.J. 198, 223-24 (1998).

4. See Xianfa [CONSTITUTION] art. 6 (1982) (P.R.C.) (enshrining "socialist public ownership of the means of production, namely, ownership by the whole people").

5. Liu Hongru, Vice Minister of the State Commission for Restructuring the Economic System, remarked that "we resolutely oppose ... privatization. But we do not because of that oppose the stock market." See Blumental, supra note 3, at 223-24.

6. See, e.g., Barbara Bradley, Burma Capitalism is Half-Baked But on the Rise, CHRISTIAn SCI. MonitoR, Jan. 25, 1995, at 8 (discussing the government's abandonment of "the Burmese Road to So- 
Part II of this article examines the general framework of the privatization debate, focusing on both the ideological and the economic underpinnings of the Chinese experience. Part III studies the first sequence of reform, involving the creation since 1978 of a non-state sector coexisting on a parallel track with the state sector and consisting of various types of property arrangements: private enterprises, collective enterprises referred to as township village enterprises ("TVEs"), and foreign-invested enterprises. I argue that the success of this first phase of reform can be explained by the government's emphasis on entrepreneurship and, consequently, the creation of new firms rather than the restructuring or destruction of existing ones. It is only in this new, non-state sector that the fundamentals of a market economy-for example, entry and entrepreneurship, exit and bankruptcy-have been established. Part IV studies the second phase of reform, undertaken to inject a system of managerial incentives designed to improve enterprise efficiency without altering the state's dominant ownership rights in its state enterprises. As I argue, this move toward decentralization and greater firm-level autonomy to demarcate the firm as an entity separate from the state-within a context of partial reform-has unwittingly created autonomy without governance, resulting in managers or agents who are insufficiently monitored by owners or principals. Part V analyzes the third and current phase of reform-the gradual transformation in the ownership base of state enterprises-from complete state ownership to a shareholding system defined by majority state shareholding and minority private equity participation. It is only in this current stage, twenty years after the initiation of reform in 1978, that China is pursuing privatization as that term is traditionally understood: transferring state ownership rights to private interests.

Even here, however, China's strategy for state-sector privatization remains radically different, in both motivation and implementation, from Russian or Eastern European privatization. As I demonstrate in Part V, state-sector privatization in China is pursued only after a vibrant non-state sector has been established-not for the purpose of allowing private entities greater ownership and control over enterprises, but perversely and ironically the exact reverse-to allow the state to exercise greater ownership and control over a vast pool of privately-held capital hidden in the non-state sector. Secondly, state-sector privatization is limited and distorted, again by ideological constraints: (1) the number of state-owned enterprises that are privatized because of a quota system only recently abolished; (2) the type of enterprises that are allowed to be listed on the securities exchanges (state, not private, enterprises); and (3) the percentage

cialism" in favor of a free market by privatizing farming and other industries); Cuba, COUNTRY REP., Jan. 30, 1995, available in LEXIS, World Library, Courep File (explaining that by the end of 1994, the government had allowed some concessions to a mixed-market economy, for example permitting farmers to sell above-quota surplus at market prices); David Lamb, Vietnam Takes Small Step with Big Board, L.A. Times, Aug. 23, 2000, at C1 (discussing Vietnam's nascent stock exchange and the pending U.S.-Vietnam trade agreement as signs of Vietnam's continuing journey toward a socialist free market); Mongolia: Bare Cupboards, ECONOMIST, Nov. 26, 1994, at 37 (discussing Mongolia's adoption of a market economy through privatization and foreign investment). 
(a strict minority) of shares in listed enterprises that can be privately owned and traded.

Despite an auspicious beginning through the creation of a non-state sector, however, the current state of Chinese privatization remains deeply flawed. While the initial deferral of state-sector privatization in favor of first creating a marketized, non-state sector was, I argue, an economically wise strategythough understandably a political disappointment for pro-democracy forcesthe government's current lethargic response toward solving the problems associated with its economically bankrupt state sector-through its insistence on maintaining rigid political control over the privatization process and its continued subsidization of money-losing state firms-has created an economically untenable situation. Economic growth from the non-state sector is merely offset by losses in the state sector, as gains produced by the non-state sphere and deposited as household savings into state banks are turned into unrecoverable bank loans used by the government to salvage decrepit state enterprises. Reform has been turned into private subsidization of public-sector inefficiencies. To the extent that state-sector privatization has been undertaken at all, it has been on the whole uneven, due primarily to the government's preoccupation with political control at the expense of economic efficiency.

Perhaps even more disturbing than the distorted and politicized manner in which privatization is undertaken, however, is the fact that China is now-as Russia was at the start of its privatization campaign-so wholly consumed by the flawed logic of privatization itself-that is, the logic of "who owns what"that it has neglected the establishment of key institutional mechanisms absolutely critical to making privatization, and consequently the question of "who owns what," work. Thus, privatization of the state sector, like the restructuring of state enterprises before it, continues to be unaccompanied by a governance regime that minimizes transaction costs and ensures that rights of ownershipwhether state or private-are exercised in asset-enhancing ways. In stage three of reform, China has wholly submitted to the privatization agenda of Western advisers-even as it publicly denounces privatization-as it focuses on the liberation of firms and managers from the state's strictures without also imposing the necessary constraints. While the government has imposed an excess of politically motivated regulation to ensure state control of the market, it has neglected to establish the market-based regulation needed to ensure market efficiency.

Whether current privatization efforts can work will depend on the government's ability to muster the will necessary to relinquish political control and allow the rudiments of the market to function. Continued subsidization of too many state firms has meant the continuation of political, rather than commercially-based, provisions of capital, which has in turn meant too little, if any, bankruptcy-induced exit for economically insolvent enterprises. China has avoided the costs of premature privatization suffered by Russia by first fostering a thriving non-state sector. However, unless it takes the necessary actions to 
move its state sector away from the central plan, toward the market and, equally important, to create institutions that are needed to make a market function, it will suffer the costs of deferred privatization and economic distortion. State-sector privatization simply to install private firms and nominal private owners is not sufficient to create a functioning and transparent market, unless it is also accompanied by a regime of corporate governance that incorporates insights from information and transaction-cost economics to ensure that owners and managers act in ways that maximize competition and efficiency and minimize predation and opportunism.

One can only hope that if China had to embrace, in 1978, at the beginning of reform, an ideologically-based strategy to avoid political transformation and democratization, and in the process also bypass some of the economic chaos and disillusionment associated with immediate state-sector privatization, the economic benefits this strategy have so far generated will not be squandered by the government's antiquated insistence on Party control over the economy. At the same time, however, as I hope to demonstrate, the critical view that the Chinese experience is either irrelevant or inconsequential, or that China is but a recalcitrant adherent of the old ways while others zip toward a more enlightened path, is a grossly incorrect one. Those who have argued for more and faster privatization of the conventional kind to expedite the transition to capitalism, regardless of the considerable social consequences (for example, the unappealing situation in Russia), are partisans of a hotly contested political position-no less political, perhaps, than the Chinese officials who have argued for their own particular political position of a slower, two-track privatization process.

\section{II}

\section{The Privatization Debate: China And EASTERn Europe}

China began its privatization policy by introducing a market economy, that is, by creating a non-state sector consisting of non-state enterprises. "[A]t its broadest level, the term 'privatization' refers merely to the introduction of some private enterprise into the economy. For example, enacting a law which allows an artisan to become self employed is a form of privatization." ${ }^{8}$ This mode of privatization is considered to be rather primitive: "This meaning of privatization was relevant to developments in Eastern Europe less than three to five years ago. Now ... for the most part Eastern European economies have moved far beyond these initial stages." Thus, "in the context of Eastern Europe," pri-

7. See, e.g., Jeffrey Sachs \& Wing Thye Woo, Understanding the Reform Experiences of China, Eastern Europe and Russia, in FROM REFORM TO GROWTH: CHINA AND OTHER COUNTRIES IN TRANSITION IN ASIA AND CENTRAL AND EASTERn Europe 31-33 (Chung H. Lee \& Helmut Reisen eds., 1994).

8. Richard M. Phillips \& Marian G. Dent, Privatizing Eastern Europe: A Challenge for the Nineties, in JOINT VENTURES AND PRIVATIZATION IN EASTERN EUROPE 445, 448 (PLI Commercial Law \& Practice Course Handbook Series No. 575, 1991).

9. Id. at 448 . 
vatization means the transfer of state-owned enterprises "to private ownership ... . For example, in Czechoslovakia, Poland and Hungary, the term privatization is generally used to refer to a specific program for the wholesale divestment of state enterprises." progressed as far towards a Western style economy (for example Romania and Albania), privatization may merely refer to the efforts of individual SOEs [state-owned enterprises] to introduce an element of private ownership or to create a joint venture with private firms."

Whether privatization is to involve "merely" the introduction of some elements of a market economy or the actual privatization of state enterprises, "privatization, in the environment of the transitional economies, is not a simple transfer of ownership from state to private individuals. It is rather a process by which the very institution of property, in the sense in which lawyers and economists employ the term, is reintroduced into... [the economy]." "12 Unlike Western European privatization, for example, where privatization means simply a sale of state assets to an already existing private sector, ${ }^{13}$ privatization for transitional economies requires not only the restructuring of the economy but also the creation of private property and the institutions of a market economy, while ensuring a maximization of economic growth and a minimization of social, economic, and political disorder. Thus, for transitional economies, additional questions arise concerning both the optimal pace as well as the sequencing of reform. If a choice were possible ${ }^{14}$ and given the limitation of resources,

10. Id. at 445,448 . Note that even in the Czech Republic, private companies started after the 1989 revolution appear to be more successful than privatized formerly state-owned enterprises. See Alla Vetrovcova, Czech Toys Ready to Play, PRAgUe Post, Dec. 2, 1998, available in LEXIS, News Library. For a discussion of the economic benefits of creating new private businesses versus privatizing old state-owned enterprises, see infra notes 44-59 and accompanying text.

11. Phillips \& Dent, supra note 8, at 448-49.

12. ROMAN FRYDMAN \& ANDRZEJ RAPACZYNSKi, PRIVATIZATION IN EASTERN EuROPE: Is THE STATE WITHERING AWAY 10 (1994).

13. State enterprises that were privatized in Great Britain, for example, "had to operate in competition with other private companies and their managerial system (even if often less efficient than that of their private analogs) was basically a product of the surrounding capitalist business culture." Id. at 21. For example, sales of British Airways, British Steel, and British Telecom took place in a "fundamentally market environment dominated by private property." Id.

14. Some scholars have commented that countries with a huge and heavily subsidized state sector, for example, Russia, would have had a difficult time deferring state-sector privatization. See, e.g., Sachs \& Woo, supra note 7, at 25. According to Sachs and Woo, China's model works only in the context of its particularly unique initial conditions: a small state sector and a large rural sector with excess labor unprotected by social subsidies, allowing the government to "release" its agricultural laborers into the newly created private sector. Unlike China, Russia did not have a large agricultural sector with surplus labor eager to take advantage of a new non-state economy, even if Russia had focused on creating such a parallel non-state sector. Rather, Russia had a large and heavily subsidized state sector employing a large number of workers uneager and unwilling to leave the security of the state sector for the vicissitudes of an unsubsidized private sector. Without a reservoir of rural workers to shift with relative ease into a newly legalized private market and additionally burdened with a gargantuan state sector, Russia, thus, had no other option but to engage in immediate privatization of its state sector, which, according to Sachs and Woo, employed 93\% of Russia's labor force in 1985 while China's state sector employed only $18 \%$ of the Chinese labor force in the 1980 s and its rural sector about $75 \%$. See Jeffrey Sachs \& Wing Thye Woo, Reform in China and Russia, ECON. POL'Y, Apr. 1994 at 108, cited in Vincent Benzi- 
should privatization of state enterprises proceed before the institution of a market economy? Or should a market-oriented framework be established first before state-sector privatization $?^{15}$

For Eastern Europe and Russia, it was presumed that the transfer of ownership rights from state to private hands creates a regime of transparent property arrangements, and thus such transfer was deemed a prerequisite for the establishment of a market economy. ${ }^{16}$ This property-rights focus has caused the debate to be framed primarily in terms of "to whom" and how quickly rights should be transferred. State firms, subject to the control of too many different actors such as governmental agencies and departments, ${ }^{17}$ lack the right of control and the right of return - the two main indicia of ownership ${ }^{18}$ - and hence suffer from incentive and performance-related problems. ${ }^{19}$ The rights of ownership must be granted to the right actors-private owners whose rights must in turn be protected by a property-rights regime consisting of clear and legally enforceable claims of ownership. Within that context of clearly defined private property rights, the natural incentives of private ownership can flow, and a free

ger, Can China's Gradualist Reform Strategy Be Applied in Eastern Europe 18 (July 1997) (unpublished report, on file with Asia Pacific Research Center, Stanford University).

For a critique of this argument, see Benziger, supra; Joseph E. Stiglitz, Whither Reform? Ten Years of the Transition (World Bank Annual Bank Conference on Dev. Econs., Wash., D.C., Apr. 28-30, 1999); see also Barry Naughton, Reforming a Planned Economy: Is China Unique?, in From REFORM TO GROWTH, supra note 7, at 49, 67-68.

15. In a recent article devoted to the economic downturn in Russia since the breakup of the former Soviet Union, the same question was posed as follows: "One issue overarched all others and would haunt the policy and its implementation down to the present. It was whether reform should push, hell for leather, the privatization of state assets or if institutions and a market infrastructure should be developed first.” John Lloyd, The Russian Devolution, N.Y. TIMES, Aug. 15, 1999 (Magazine), at 36.

16. See id. at 38. Yegor Gaidar of Russia

was determined to proceed with the privatization of state assets, which all the reformers agreed would break the power of the Communist-era bosses and was, accordingly, at least as much a political as an economic policy. It was an article of faith that privatization would foster honest dealings and civic behavior by creating a middle class with a stake in the country ....

Id.; see also Kimio Uno, Privatization and the Creation of a Commercial Banking System, in WHAT Is To Be Done? Proposals For the Soviet Transition to The Market 150 (Merton Peck \& Thomas Richardson eds., 1991) (arguing that privatization of state enterprises is required because "only private owners can establish an enduring basis for self-financing and managerial independence"); Martin Weitzman \& ChengGang Xu, VAguely Defined CoOperatives and CoOperative Culture: A RECONCILIATION OF A PARAdOXICAL PHENOMENON IN TRANSITIONAL ECONOMIES 2

(Harvard Inst. of Econ. Research Discussion Paper No. 1607, 1992).

To a western-trained economist, the centrality and immediacy to any transformation process of establishing well-defined property seems so self evident as to hardly merit discussion. It is little wonder that ... the officially sanctioned position of Western governments and international lending organizations places the highest priority on the aggressive and rapid establishment of well-defined property rights.

Id. Privatization is deemed necessary not only to correct market incentives but also to clarify muddled property relations and rights.

17. See, e.g., Yair Aharoni, State-Owned Enterprise: An Agent Without a Principal, in PuBLIC ENTERPRISE IN LESS-DEVELOPED COUNTRIES 69 (Leroy Jones ed., 1982).

18. See generally PAul Milgrom \& John Roberts, ECONOMICS, ORganization, AND MANAGEMENT 288-89 (1992); Sanford J. Grossman \& Oliver D. Hart, The Costs and Benefits of Ownership: A Theory of Vertical and Lateral Integration, 94 J. POL. ECON. 691 (1986).

19. See, e.g., MAXIM BOYCKO ET AL., PRIVATIZING Russia (1995). 
market that responds to information provided by price signals will allow producers to respond correctly in accordance with the laws of supply and demand. ${ }^{20}$ If a free market exists-if property rights are clearly delineated and prices freely reflect supply and demand-assets will be transferred to those willing to pay the most, resulting in the most efficient allocation of resources. This, in essence, is the Coase Theorem: As long as property rights are created, they will move to the highest-valued use, ${ }^{21}$ unless transaction costs are high enough to prevent an efficient reallocation of resources. ${ }^{22}$ The institution of a legal framework with rules that lower transaction costs is thus absolutely crucial. As Coase observed,

the rights which individuals possess, with their duties and privileges, will be to a large extent, what the law determines. As a result, the legal system will have a profound effect on the working of the economic system and may in certain respects be said to control it .... It makes little sense for economists to discuss the process of exchange without specifying the institutional setting within which the trading takes place. ${ }^{23}$

Under a system of state ownership, assets will not be transferred on the open market even to the highest bidder. Privatization of the state sector is therefore necessary to reallocate resources on a more efficient basis. Given the

20. See MilgROM \& Roberts, supra note 18 , at 288.

21. See generally RONALD H. COASE, Notes on the Problem of Social Cost, in THE FIRM, THE MARKET, AND THE LAW 157 (1988); Ronald H. Coase, The Federal Communications Commission, 2 J.L. \& ECON. 1 (1959).

Whether a newly discovered cave belongs to the man who discovered it, the man on whose land the entrance to the cave is located, or the man who owns the surface under which the cave is situated is no doubt dependent on the law of property. But the law merely determines the person with whom it is necessary to make a contract to obtain the use of the cave. Whether the cave is used for storing bank records, as a natural gas reservoir, or for growing mushrooms depends, not on the law of property, but on whether the bank, the natural gas corporation, or the mushroom concern will pay the most in order to be able to use the cave. One of the purposes of the legal system is to establish that clear delimitation of rights on the basis of which the transfer and recombination of rights can take place through the market. Id. at 25 .

22. See generally RonAld H. COASE, THE FIRM, THE MARKET, AND THE LAW, supra note 21 (discussing how transaction costs are part of any institutional framework, although they can be higher or lower depending on the existence or nonexistence of certain rules. For example, transaction costs would be higher in a regime with no rules against fraud, or rules on fiduciary duty, because the relevant economic actors would have to engage in more investigation and monitoring to protect their interests).

23. Ronald H. CoAse, The Institutional Structure of Production 7 (University of Chicago Occasional Paper No. 28, 1992); see also Ronald H. Coase, The Choice of Institutional Framework: A Comment, 17 J.L. \& ECON. 493, 493 (1974) ("[T]he way in which property rights are defined can affect the costs of transactions, [and] any change in those rights will affect the transactions that are carried out."). Having the appropriate legal system, of course, is not the only way in which transaction costs might be lowered. There are non-legal or extra-legal mechanisms as well, such as norms of trust that govern the behavior of community members. See, e.g., Lan Cao, Looking at Communities and Markets, 74 NOTRE DAME L. REV. 841, 863-74 (1999) (discussing how social norms, particularly those based on a community's common cultural base, guide community behavior, promote trust, lower transaction costs, and hence promote exchanges among community members); Stewart Macaulay, Private Legislation and the Duty to Read-Business Run by IBM Machine, the Law of Contracts and Credit Cards, 19 VAND. L. REV. 1051, 1061 (1966) (describing how trust obviates the need to engage in "a suspicious line-by-line analysis of the writing"). 
ever-present possibility that old, entrenched interests may reassert themselves, ${ }^{24}$ and given "the Coasian idea that the initial private owners didn't matter too much as 'the market' would soon reallocate the assets to the efficient owners," 25 privatization should be undertaken as quickly as possible. Government predation, not market failure, was the immediate problem. ${ }^{26}$

That is the approach adopted by Russia and favored by Western advisers. ${ }^{27}$ In two years, between 1992 and 1994, for example, Russia transferred shares in more than 11,000 state enterprises constituting more than seventy percent of its

24. Under the theory that the state's many grabbing hands preyed upon and interfered with private firms, privatization is a necessary corrective to state predation. See generally ANDREI SHLEIFER \& ROBERT VISHNY, THE GRABBING HAND: GOVERNMENT PATHOLOGIES AND THEIR CURES (1998).

25. Stiglitz, supra note 14, at 19.

26. See SHLEIFER \& VISHNY, supra note 24, at 11 (Russian privatization "de-emphasized corporate governance precisely because the intent was to reduce the damage from government failure rather than from market failure."). This does not mean that Russian reformers undertook the task of privatization and ignored all else. It only means that given limited resources, "privatization became a major fetish while competition policies and other market regulations were seen as minor afterthoughts." Stiglitz, supra note 14 , at 20 n.37.

27. Largely overlooked by economists and advisors is the New Economic Policy "NEP," the Russian privatization experiment of 1919-28. After the Bolshevik coup d'etat in 1917 and the ensuing largescale nationalization, Russian industrial production was at $13 \%$ of its pre-WWI volume, the grain harvest had fallen more than $50 \%$, coal output and iron ore extraction dropped $70 \%$ and $93 \%$, respectively, and GNP and average monthly wages fell by more than $60 \%$. See Gerhard Rempel, Russian New Economic Policy (visited Dec. 4, 1999) < http://mars.acnet.wnec.edu/ grempel/courses/russia/ lectures/31nep.html>; NEP: Capitalism for a Day, MOSCOW TIMES, Feb. 6, 1996, available in LEXIS, News Library. In 1918, in response to these problems, the Communists adopted a tactical denationalization of small-scale industry and restoration of market economy known as the "NEP." See Adam J. Albin, Comment, Joint Venture Law in the Soviet Union: The 1920s and the 1980s, 9 J. INT'L L. BuS. 633 (1989); see also NICHOLAS RIASANOVSKY, A HISTORY OF RUSSIA 490-91 (4th ed. 1984); RUDOLPH SCHLEsinger, SOVIET Legal THEORY: ITS SOCIAL BACKGROUND AND DEVElopment 84-90 (1945). The state kept control only over banking, foreign trade, and large-scale industry. See NEP: Capitalism for a Day, supra. In 1920, a new tax system allowed peasants to pay tax in kind (fixed at $10 \%$ by 1921). By 1922, peasants were permitted to lease land and hire labor, and two thirds of government revenue was coming from the food tax and a variety of direct money taxes. See Rempel, supra. Seventy-five percent of retail trade was in private hands by 1923 . By 1924, private enterprises accounted for more than $50 \%$ of butter and eggs production and as much as $50 \%$ of the grain production in some parts of the Soviet Union. Even large state-owned enterprises were ordered to operate on a commercially-reasonable basis, which meant that other state enterprises were no longer given priority in the allocation of goods and services and had to compete with private contractors. By $1925,50 \%$ of all state-manufactured consumer goods were sold to private traders. See NEP: Capitalism for a Day, supra. The fruits of the quasi-market economy were spectacular and impressed even foreign observers. See id. (citing ARMAND HAMMER, QUEST OF THE ROMANOFF TREASURE (1932)).

This economic success, however, led to social antagonism; Orthodox Bolsheviks started viewing the policy as a resurrection of capitalism and finally stopped the experiment out of political fears of its success. In 1925, the state re-instituted control over the prices on basic industrial materials, fuels, and freight transport, as well as control over the production and distribution of key commodities. Credits began to be disbursed administratively and were often denied to private enterprises. See Rempel, supra; NEP: Capitalism for a Day, supra. In 1926-27, a campaign to eliminate the "new bourgeoisie" was in full swing. Private trade was cut almost by $50 \%$ by 1928 and the Soviet Union's first five-year state economic plan was initiated. By 1930, private enterprise became marginal, practically non-existent. The result was a severe deficit of food and consumer goods that lasted until 1993. See RIASANOVSKY, supra at 490-92; NEP: Capitalism for a Day, supra.

For a discussion of Russia's current posture toward the private sector (as opposed to its privatization of the state sector), see infra notes 40,43 , and 65 . 
industrial sector to private holders. ${ }^{28}$ Yet, "[t]he Coasian argument that there would be a quick reallocation of assets to 'efficient' producers failed in part because there was no genuine secondary market for the same reasons that there was no real primary market-so the assets were 'looted' rather than resold." ${ }^{29}$ The Coasian model, in other words, could not work because the privatizers did not create the institutional framework to minimize transaction costs and facilitate the subsequent reallocation of resources to the highest-valued use.

China, by contrast, has pursued the exact opposite strategy, which has allowed it to sidestep the issue of reallocation and highest-valued use altogether, at least in its first phase of reform. Chinese reformers deferred state-sector privatization and focused on establishing the fundamentals of a market-oriented economy-in other words, a working market-in the newly created non-state sector. As I discuss in Parts III, IV, and V, however, in the Chinese context, a market-oriented economy that functions on commercial rather than politicized terms has been established, unfortunately, only in the non-state sector-hence the rapid growth and increased productivity of non-state enterprises. The Chinese state sector, on the other hand, continues to languish despite state-sector privatization because of the absence of key institutional mechanisms necessary to make privatization work. Yet, as the Chinese should have learned from the lessons of Russia, transferring state assets to private entities-without regulatory safeguards designed to lower transaction costs and ensure the effective workings of a market-will not result in market growth and efficiency. Indeed, the "privatize now, regulate later" approach might even result in the creation of vested interests that oppose later efforts to "regulate away" their early gains achieved in the initial stages of unregulated privatization..$^{30}$

Political and ideological considerations were among the factors that prompted Russia and many Eastern European countries to engage in speedy and mass privatization of state-owned enterprises ${ }^{31}$ and China to favor insula-

28. See John S. EArle et Al., Ownership Structures, Patterns of Control AND ENTERPRISE BEHAVIOR IN RUSSIA 1 (Centre for Economic Performance, London Bus. Sch. Discussion Paper No. 315, 1996).

29. Stiglitz, supra note 14 , at 20.

30. Id.

31. Political consideration - the concern that Russia's and Eastern Europe's unique historical moment had to be decisively seized to ensure against political backlash and the return of Communist power-was one among the many factors that prompted immediate state-sector privatization in Eastern Europe. See, e.g., U.S. Policy Toward the Former Soviet Union: Hearings of the House Foreign Affairs Comm., 103d Cong., 2d Sess. 3 (1994) (testimony of Strobe Talbott, Deputy Secretary of State) ("Our approach in assembling last year's foreign assistance program was to reinforce those trends in Russian political and economic life that together, we believe, constitute the essence of the great transformation underway in that country. Those trends are democratization and privatization."); Jeffrey Sachs, Accelerating Privatization in Eastern Europe: The Case of Poland, in PROCEEDINGS OF THE World BANK ANNUAl CONFERENCE ON DEVElopMENT ECONOMIES 15 (1991) ("The need to accelerate privatization is the paramount economic policy issue facing Eastern Europe. If there is no breakthrough in the privatization of large enterprises in the near future, the entire process could be stalled for years to come.”); Catherine Mann et al., Political and Economic Consequences of Alternative Privatization Schemes 8 (Conference on Markets, States, and Democracy: The Political Economy of Post-Communist Transformation, sponsored by the Center for German and European Studies at the University of California, Berkeley, and the Friedrich Ebert Stifftung (Feb. 11-13, 1993)) ("Speed is im- 
tion of the state sector from private economic encroachments and preservation of social ownership. ${ }^{32}$ While remaining nominally socialistic, Chinese reformers argued against ideological purity in favor of economic pragmatism. ${ }^{33}$ Thus, Deng Xiaoping referred to a Sichuan proverb, "[i]t does not matter if it is a yellow cat or a black cat, as long as it catches mice," ${ }^{34}$ to make the case for reducing the role of central planning and expanding the role of markets. At the same time, however, market creation and expansion, while an economic imperative, must be subordinate to the state sector and contained within doctrinally acceptable perimeters. ${ }^{35}$ Thus, a non-state sector separate from public ownership of the means of production- "markets at the margin, parallel to central planning, ${ }^{, 36}$ was created even as the state sector itself was preserved. Despite an almost complete absence of International Monetary Fund ("IMF") programs - or as some claim, precisely because of the absence of bad IMF advice $^{37}$ - Chinese privatization is now characterized by an "increasing market orientation ... in ownership, production, investment, and demand" ${ }^{38}$ and guided by an overarching criteria of "balancing growth with stability, order with dyna-

portant, since proceeding slowly risks allowing political opposition to develop that could weaken and perhaps unravel progress achieved to date.").

China's strategy of deferring state-sector privatization also has political and ideological roots: the desire to maintain a foundation of state ownership. See infra Parts IV and V.

32. Arkady Volsky, President of the Russian Association of Industrialists and Entrepreneurs and leader of the Civic Alliance, suggested that Russia should learn from China's experience where "reforms have not been accompanied by declining living standards." Yelizaveta Leontyeva, Power Struggle Goes on Against Background of Economic Dislocation, RUSSIAN PRESS DIGEST, Nov. 1, 1992, available in LEXIS, News Library. However, Russian ex-prime minister Yegor Gaidar disagreed. He stated that Russia could not use China's model, because,

[i]n China, effective state discipline was combined with consistent promotion of business activity, and a powerful structure of authoritarian rule was preserved. Any attempts by the opposition to destabilize the situation there were ruthlessly suppressed. ... There is no division of powers in China, and no nascent democracy, and it is not a federal state. To follow the Chinese path, Russia should have elaborated a political strategy different from the one the Russian Parliament voted for in 1990.

Sergei Chugayev, Gaidar Presents a Government Program to the Deputies, RussiAn PRESS DIGEST, Oct. 6, 1992, available in LEXIS, News Library.

33. Even when referring to so capitalist an institution as the stock market, Wei Wenyuan, chief executive of the Shanghai Stock Exchange, insisted that "when we think about the development of our economy, we have stopped thinking about whether it is socialism or capitalism." Michael Hirsch, China's Financial Revolutionaries, InSTITUTIONAL INVESTOR (Int'l ed.), July 31, 1993, at 43, 51. Similarly, Huang Guixian, an executive at Shanghai Shenyin Securities, remarked, "We used to decide first if something new was socialist or capitalist .... Now we see whether it works, then decide whether it is socialist or capitalist." Id. Under Deng Xiaoping, "practice [is] the sole criterion of truth." Gerrit Gong, China's Fourth Revolution, 17 WASH. Q. 26, 35 (1994).

34. Deng Xiaoping, How to Recover the Agricultural Production, in SElECTED WORKS OF DENG XIAOPING (1938-1965), at 292, 293 (1992).

35. See Kenneth Lieberthal, Governing China: From Revolution Through Reform 128-44 (1995) (describing the Chinese plan of ensuring that market reform be contained within a "bird cage").

36. Wei Li, A Tale of Two Reforms, 30.1 RAND J. ECON. 120 (1999).

37. See generally Lloyd, supra note 15 , at 38 . The IMF embraced privatization of state enterprises as the linchpin of market reform. See InTERnAtional MONETARY Fund ET AL., ThE ECONOMY OF THE USSR: SUMMARY AND RECOMMENDATIONS 26 (1990) ("The ultimate goal of ownership reform is to privatize almost all enterprises.").

38. Gong, supra note 33, at 35. 
mism, change with constancy." ${ }^{\prime 39}$ China, in other words, took a politically induced path that allowed it to avoid many of the economic problems associated with Russian privatization. ${ }^{40}$ As the World Bank's chief economist has noted recently in his controversial critique of the IMF's role in Russian privatization, "those who put privatization above all else were clearly wrong .... [They] thought that you had to pursue privatization, and infrastructural change would follow. They thought that the new owners of private property would demand that this happen. But instead they took their money out.",

Chinese departure from the conventional wisdom that prevailed in Russia and Eastern Europe-by merely adopting a "traditional form of privatization [that] occurs when the state withdraws altogether from certain economic activities and creates an opportunity for private entrepreneurs to act in such fields" ${ }^{\prime 2}$ - has produced a prosperous non-state economy only tenuously connected to the state sector. Why has Russia, which moved to dismantle an inefficient economic system as exhorted by Western advisers such as the IMF, experienced a perpetuation of inefficiency and persistent economic downturns? ${ }^{43}$

39. Id. The fear of social instability is understandable for a country like China, with an estimated $1,152,428,417$ individuals and 300,388,130 households in 22 provinces, five autonomous regions, and three special municipalities. $I d$. at 30.

In contrast, Western-led reform in Russia, as noted in a recent article by World Bank Chief Economist Joseph Stiglitz, took

an ideological, fundamental and root-and-branch approach to reform-mongering as opposed to an incremental, remedial, piecemeal and adaptive approach .... Some economic cold warriors seem to have seen themselves on a mission to level the "evil" institutions of Communism and to socially engineer in their place the new, clean and pure "textbook institutions" of a private property market. Lloyd, supra note 15 , at 36.

40. "Why, then, does Communist China have growth rates and foreign investment that put Russia to shame? ... Perhaps because ... China ... provided a semblance of order, thereby allowing the creation of totally new businesses." Jonas Bernstein, Party Lines: A Transition For Russia, But to What? Moscow TIMES, Apr. 2, 1999, available in LEXIS, News Library. Indeed, Russian state support and protection of private enterprise was always largely rhetorical. The State Committee to Support Private Enterprise was short-lived. Small businesses, often subjected to racketeering practices of organized crime, were never sufficiently protected by law enforcement. See Kirill Koriukin \& Alexander Gordeyev, Small Firms Retreat Into Shadow, Moscow TIMES, Oct. 8, 1998, available in LEXIS, News Library; Natasha Mileusnic, U.S. Security Firm Joins War on Crime, MosCOW TIMES, Apr. 7, 1995, available in LEXIS, News Library.

41. Lloyd, supra note 15, at 39. Ironically, one of the primary reasons Russian privatization took the path it did was precisely to forestall political opposition from interest groups with a stake in the old enterprise, such as labor unions and ex-Party members, who may scurry to "get their tentacles around the state enterprises." Sachs, supra note 31, at 16.

There have been quick responses to Stiglitz' report; see Stiglitz, supra note 14, which blames the failure of the Russian economy on reform that neglects institution building. See Sick Patients, Warring Doctors, ECONOMIST, Sept. 18, 1999, at 81. Those condemned by Stiglitz denied that there was insufficient emphasis placed on institution building and legal reform. Anders Aslund of the Carnegie Endowment for International Peace has been more blunt: "Stiglitz is a striking embarrassment to himself and the World Bank. Without knowing anything, he mouths any stupidity that comes to his head." Id.

42. Tamas Horvath, State Shrinkage in Hungary in the 1980s, in PRIVATIZATION AND Deregulation in Global Perspective 413 (Dennis J. Gayle \& Jonathan N. Goodrich eds., 1990) (emphasis added).

43. At least three historical reasons complicated the process of Russian privatization, whether its privatization of the state sector or its construction of a private sector. First, following the NEP experiment, see supra note 27 , Russian private enterprise was effectively eradicated (in contrast to the situa- 
And why has China, which preserves an inefficient economic system against outside advice, experienced, for the most part, increased efficiency and economic growth?

There are sound socioeconomic reasons for committing resources to the creation of a viable market framework instead of the adaptation or destruction of the old state sector. For centrally planned economies like China, creating a new market might entail merely removing state barriers and allowing a private entrepreneurial spirit to take over. As there are transaction and opportunity costs to both the privatization of state enterprises and the creation of a distinct non-state sector, a transitional economy with limited resources might be faced with a tradeoff-doing what, when. " "There was always the facile recommendation that 'everything is important' and 'everything should be done at once.' But real choices are always necessary given the real limitations on any government's time, focus, and resources." ${ }^{45}$ Limited financial and creative resources can be used either to devise auction schemes, outright sales, voucher distribution, and other intricacies required to implement state-sector privatization, ${ }^{46}$ or it can be used to finance and facilitate the growth of new companies through the

tion in Poland, where private enterprise, "however limited in scale, has been preserved not only in the agricultural sector but in handicrafts, trade and service sectors as well."). Leonid Fridman, Reform and Its Advisers, MOsCOW TIMES, Feb. 11, 1998, available in LEXIS, News Library. Second, throughout its history, the Soviet Union promoted heavy industry at the expense of other sectors, especially those that required individual initiatives, which in turn discouraged and dampened the entrepreneurial spirit. See id. Third, the initial privatization experiment, the voucher experiment of 1992 (providing each citizen with one voucher worth 10,000 rubles to be used for the purchase of shares of state companies or registered investment funds, or to be traded in the market), was largely a fiasco and further dissuaded entrepreneurial spirit. Most citizens chose to turn in their vouchers to investment funds, many of which exploited the people's trust by collecting large amounts of vouchers only to disappear without a trace. Yuliya Mitrofanskaya, Privatization as an International Phenomenon: Kazakhstan, 14 AM. U. INT'L L. REV. 1399, 1415 (1999).

In addition, the state's emphasis on its mass privatization program essentially overwhelmed and "smothered" other possible reform efforts. Approximately 85,000 small enterprises and 14,000 medium and large enterprises have been transferred to private hands. In 1997-98, privatization continued with the sale of 70 large enterprises yearly, some of which included oil, energy, and telecommunications companies. Mitrofanskaya, supra, at 1414-17. Simultaneously, the employees could choose either (1) to receive $25 \%$ of the stock shares to the workers and have an option to buy another $10 \%$ at a discount (with the state retaining the minimum of $60 \%$ ) or (2) to receive $51 \%$ of the common shares (with the state retaining the minimum of $49 \%$ ). In any event, only $20 \%$ of the state-retained shares were voting, thus effectively limiting the level of state control. See Christopher F. Dugan \& Vladimir Lechtman, Current Development: The FCPA in Russia and Other Former Communist Countries, 91 AM. J. INT'L L. 378, 382 (1997). This emphasis on privatizing the state sector might have contributed to a de-emphasis on establishing a new, private, sector.

44. For example, "the creation of a commercial code is probably more important to the new entrepreneurs who are building new commercial relationships and who do not have the backing of the state, than to the state-sector firms with their traditional ties." Peter Murrell, Evolution in Economics and in the Economic Reform of the Centrally Planned Economies, in THE EMERGENCE OF MARKET ECONOMIES IN EASTERN EUROPE 35, 51 n.32 (Christopher Clague \& Gordon C. Rausser eds., 1992). A tradeoff in opportunity costs occurs, for example, when the creation of a private-sector framework of predictable and transparent laws receives lower priority from the government than the design and implementation of state-sector privatization schemes.

45. Stiglitz, supra note 14, at 19.

46. For an account of the privatization methods used in Eastern Europe, see BUTTERWORTHS Privatisation In CENTRAL AND EASTERn Europe (Stephen A. Rayner ed., 1992). 
removal of barriers to entry and the institution of commercial codes, legal procedures, and a tax collection system. As some economists have noted,

too many hopes have been invested in privatization and rather too much intellectual, social, and political capital is being consumed in the process of privatization. The argument is strengthened when the efforts behind privatization are contrasted to the lack of attention being paid to creating and fostering the development of new private sector firms. ${ }^{47}$

As China experienced in its first sequence of reform, innovation and growth may come with the emergence of new firms, and not necessarily with the destruction or restructuring of established ones. One of the more significant drawbacks of a strategy that focuses on the inefficient state sector is the "understandable but nonetheless misplaced fixation on the old assets ... Important questions are what the old assets are worth and whether they are worth enough to be occupying as much time, attention, and scarce resources of politicians, finance ministries, and ministries of ownership as they have, in fact, been given." Equally significant, by establishing a separate market economy, China also avoided having to deal prematurely with the administrative complexities of valuation at a time when it would have been difficult to assign an accurate market value to assets that have previously had none, especially given the absence of a mature market, a developed pricing system, or a generally accepted accounting standard. ${ }^{49}$

Additionally, as the Chinese experience demonstrates, there can be a demonstrably positive correlation between the old, state sector and the new, nonstate one. A study of 434 Chinese cities revealed, for example, that at least in the incipient stages of reform, state firms, rather than being a drag on the new, non-state economy, might actually stimulate the emergence and growth of nonstate firms. ${ }^{50}$ Like other centrally planned economies in transition, the purchase of inputs and sale of outputs in China remain linked to the central planning system despite efforts to de-link portions of the economy from the central plan. As a result, once the state allows private businesses to enter the economic

47. Murrell, supra note 44, at 45. "In many Eastern European countries, policy toward the private sector can be characterized, at best, as one of benign neglect." Id. "[I]t is quite unusual to find authors who emphasize the costliness of the privatization process and the need to slow down this process in order to channel resources to the new private sector." Id. at 48 n.18. Instead, time, energy, and resources had to be devoted to devising and administering a vast multiplicity of schemes-for example, public offerings, public auctions, sales to private buyers or institutional investors and buyouts by insiders.

48. Anne O. Krueger, Institutions for the New Private Sector, in THE EMERGENCE OF MARKET ECONOMIES IN EASTERN EUROPE 222 (Christopher Clague \& Gordon C. Rausser eds., 1992).

49. For a detailed discussion of valuation problems, see Hans J. Blommenstein et al., Privatizing Large Enterprises: Overview of Issues and Case Studies, in CENTRE FOR CO-OPERATION WITH THE EUROPEAN ECONOMIES IN TRANSITION \& ORGANISATION FOR ECONOMIC CO-OPERATION AND DeVelopment, Methods of Privatising LARge ENTERPRISES 11, 16 (1993); David Gordon, Privatization in Eastern Europe: The Polish Experience, 25 LAW \& POL'Y INT'L BUS. 517, 531-33 (1994); Robert J. Toltzman, Valuation Issues-Problems and Solutions, in BUTTERWORTHS PRIVATISATION IN CENTRAL AND EASTERN EuROPE 61 (Stephen A. Rayner ed., 1992).

50. See Shang-Jin Wei \& Peng Lian, Love and Hate: State and Non-state Firms in Transition ECONOMIES 1 (Center for Pac. Basin Monetary and Econ. Stud., Econ. Research Dep't. of the Fed. Reserve Bank of S.F., Pac. Basin Working Paper Series No. PB93-10, 1993). 
mainstream, new firms may be able to take advantage of the already established state-sector firms involved in the "downstream and upstream of the production process," products rather than worrying about finding new input supply and output market.

By contrast, "if one closes the state firms all at once at the beginning of a reform, the existing interfirm production chains are also severed." ${ }^{52}$ The sudden destruction of state firms for the purpose of boosting efficiency and growth may itself cause a decline in growth because it may create a void in the production and distribution chain that may take years for private businesses to fill. ${ }^{53}$ The authors of the study concluded, however, that once a private or non-state sector has emerged, the dismantling of inefficient state enterprises becomes necessary.

Buoyed by the initial presence of the subsidized state sector, private firms may also take advantage of "free-riding on the social safety net" financed by the old state sector. ${ }^{54}$ For example, at the time the study was conducted, a state firm paid from forty to fifty-five percent of its profits in income tax; a collective such as a township village enterprise paid thirty-five percent; and a foreign-invested firm paid only fifteen percent if it were established in special economic zones. As a result, a Chinese family will likely take advantage of both sectors by having one person work in a state enterprise to secure social welfare benefits and another person work in the private sector to take advantage of the higher wages. $^{55}$

Besides the economic benefits, the social benefits generated by the Chinese experience are equally compelling. A dual-track approach minimizes transition costs and social instability because the preserved state sector provides an anchor during the tumultuous beginnings of the market, so new firms do not have to sink or swim but may rely, initially at least, on the established production and distribution chain provided by the preexisting state sector. ${ }^{56}$ In turn, the newly

51. Id. at 5 .

52. Id. at 6-7.

53. Hypothetically, all private entrepreneurs could form new businesses to respond to each other's supplies and demands and to provide mutual inter-firm production and distribution. However, because this scenario is unlikely to happen, the "economy can be stuck in a nongrowth equilibrium." Id. at 8 ; see also Wei Li, A Tale of Two Reforms, supra note 36, at 2:

$[\mathrm{T}]$ he disintegration of the centralized organization of production permits each monopolistic state enterprise to pursue its own monopoly profits by restricting output to the detriment of the economy as a whole .... [B] ecause the Chinese reform preserves the centralized organization of production but allows the emerging product markets, however imperfect they may be, to organize the production of the above-the-plan output, it leads to a general expansion of Id. output in the state industry.

54. WEI \& LIAN, supra note 50, at 8.

55. See id. at 9 n.6.

56. See supra notes 50-53 and accompanying text. 
established, non-state market may also cushion some of the shocks that accompany state-sector privatization by absorbing laid-off state-sector workers. ${ }^{57}$

Instead of destroying the state sector, and in the process possibly causing economic downturns triggered by the destruction of the old economy before alternative market forces have been introduced, the Chinese model, in other words, has been focused on retaining the state sector until an alternative nonstate economy can be established. The paradox has been noted: "[T]he most important aspect of the transition to a spontaneously functioning market economy cannot be initiated by market forces themselves. Indeed, the only force powerful enough to set the market forces in motion is the very state that is supposed to remove itself from the picture." 58 However, if the focus is on the creation of new economic entities and new rights rather than transferring nonexistent and non-functional rights from state firms to private holders, then it becomes evident that "the state, however much a source of problems, also happens to be the only organization capable (over the long term) of creating a property-rights system and (over the short term) of providing interim measures to stabilize firm-level incentives." 59 As I show below, the emphasis in the past twenty years in China has been on reconfiguring the economic universe to produce a synergistic relationship between the two combined state and non-state economies.

III

\section{PRIVATIZATION WITH CHINESE CHARACTERISTICS: CREATING A NON-STATE SECTOR}

China began creating its non-state sector in the 1970s by focusing on agricultural reform and adopting measures to "generat[e] huge increases in productivity, income, and output, with negligible state investment." ${ }^{\circ 0}$ With the commencement of rural reform in 1978, China became self-sufficient with regard to food production within two years. ${ }^{61}$ By doubling the incomes of its farmers, rural reforms also had political appeal because they immediately benefited 800 million people. ${ }^{6}$

Reform began not through the adoption of costly, complex, or other cumbersome measures that would have necessitated a high degree of governmental

57. See H. Lyman Miller, Holding the Deng Line, CHINA BuS. REV., Jan.-Feb. 1993, at 28. Then General Secretary Jiang Zemin, in a report reaffirming commitment to market reforms, "emphasized the urban ... sector as an area of future growth that could absorb workers displaced by reforms in the State sector." Id.

58. FRYDMAN \& RAPACZYNSKI, supra note 12, at 57.

59. Edward S. Steinfeld, Forging Reform in China: The Fate of State-Owned INDUSTRY 40 (1998).

60. William H. Overholt, The Rise of China: How ECONOMic ReForm is CReating A NEW SUPERPOWER 37 (1993).

61. See Diane Francis, Election the Only Solution for Russia: Interview with Mikhail Gorbachev, FIN. POST, Mar. 27, 1993, § 5 (Weekly ed.), at S3, available in LEXIs, News Library, ASIAPII File.

62. See OVERHOLT, supra note 60 , at 37. 
involvement or investment. The experiment in profit retention for farmers, for example, required only that "[f]actors of production ... be released to the new private sector," ${ }^{\circ 3}$ so that those in the new economy would have access to capital, labor, and land for productive purposes. In one of the most significant reform measures, China dissolved farming collectives or communes in favor of a household-based agricultural system. Assets once owned by the communes were sold to the farmers at low prices, allowing the new household-based businesses to accumulate the necessary start-up assets at a relatively low cost. ${ }^{64}$ Commune land, distributed to individual households, was converted into household land or "family plots" in which farmers were granted a "leasehold" on the land ${ }^{65}$ and then granted a high degree of autonomy and flexibility in production and sales, as long as certain production quotas owed to the state were met. $^{66}$ Under a "contract responsibility system, ${ }^{167}$ farmers organized by household units contracted with the state to sell a set quantity of produce at state price, but any surplus generated above the established quota was sold at freemarket price. ${ }^{68}$ Through the introduction of markets "at the margin," parallel to

63. Christopher Clague, Introduction: The Journey to a Market Economy, in THE EMERGENCE OF MARKET ECONOMIES IN EASTERN EUROPE 1, 11 (Christopher Clague \& Gordon C. Rausser eds., 1992). For example, "[l] and and building space should be made available; labor needs to move out of the public sector, and loans should be provided." Id.

64. See Keun Lee, Making Another East Asian Success in China, in From ReForm to Growth: supra note 7 , at $183,190$.

65. See A Survey of Perestroika, ECONOMIST, Apr. 28, 1990, at 59; Robert Wessel, Reestablishing Private Business in Previously Socialist Economies, BUS. ECON., Jan. 1992, at 30, 32. Note in comparison that the Russian rush to privatize extended to almost everything but the commune lands. Russia's Parliament (Duma) is still unable to pass a Land Code ensuring private land ownership. On July 17, 1998, the Duma's coalition of democratic parties won by a small margin over the Communist and ultranationalist blocks and refused to adopt the latest draft of the Land Code which would have prevented nearly all private ownership of land and nearly all commercial land transactions, apart from those involving small private homes and summer-home plots, full ownership of which had been legislatively conferred in 1992. The draft's apparent goal was to effectively preserve the existing state-owned collective farms (still the dominant form of farming) and make it virtually impossible for a "land owner" to sell, lease, or mortgage his or her land. See Roy Prosterman, Looming Land Code, Moscow TimES, Aug. 12, 1998, at 7. The inability to mortgage leads to the inability to obtain the necessary financing. (One farmer needs as much as 20 million rubles to start his business.) See Yelena Tokareva \& Yevgeniya Pishchkova, Everything Has Been Ploughed Up . . ., Russian PRESS DiG., July 25, 1992, at 3. Consequently, $80 \%$ of Russia's 24,000 state farms and 270,000 private farms are insolvent. See Yevgenia Borisova, Bringing in The Harvest, Moscow TIMES, Oct. 26, 1999, at 15. In an attempt to improve the dire economic situation, some regions and municipalities have passed regional mortgage bills. See Yevgenia Borisova, Samara Lawmakers Pass First Farm Mortgage Bill, Moscow TIMES, Apr. 6, 1999, at 13; Natalya Shulyakovskaya, Bill Readies Moscow to Sell Land, Moscow TiMES, Dec. 11,1998 , at 4 . However, these regional or municipal steps are subject to a possible repeal by a future federal land code and are themselves insufficient to create the necessary level of certainty to induce broad investments of banks' funds and farmers' efforts. As of October 2000, when this article was being prepared for publication, a new federal land code that would grant the right to sell and buy property has still not passed.

66. See Lee, supra note 64, at 190.

67. Wessel, supra note 65 , at 30,32 .

68. See id. at 33-34. 
the central plan, and the institution of a "dual-track pricing system," gross farm output increased within ten years by an astonishing $138 \%{ }^{69}$

This extraordinary increase in production output, plus an extraordinarily high average household saving rate estimated at twenty-three percent of disposable income ${ }^{70}$ made it possible for farmers to increase their cash reserves, which they used to finance new enterprises without having to rely on state loans. "In effect, very hard budget constraints ${ }^{71}$ were imposed on farmers (i.e., little credit was made available by the state banking system) as they entered the market economy. Further, the newly independent farmers viewed themselves as being undercapitalized for financing on-farm investments, and they began building up their cash reserves." ${ }^{22}$ From 1978 to 1996, the Chinese economy grew at an average annual rate of $9.9 \%$, with a corresponding increase in the living standards of its people. ${ }^{73}$

This capital surplus created the foundation for the emergence and proliferation of non-state enterprises, most notably, the township village enterprises ("TVEs"). The "accumulation of wealth by rural families in China led to the emergence of non-farm industrial production and corresponding markets in rural and suburban towns and townships." When the government relaxed its monopolistic grip over industry in 1979 and allowed the economy a modest shift toward light, consumer-goods manufacturing, start-up firms organized along various types of market-based ownership lines ${ }^{75}$ rushed in to fill the niche: collectives, private, foreign-invested firms, and even some firms officially categorized as state enterprises because they had been sponsored by local or provincial governments. ${ }^{76}$

69. Id. at 34. See generally BARRY NAUGHTON, GROWING OUT OF THE PlAN: ChINA's ECONOMIC REFORM, 1978-1992 (1995).

70. However, before the 1978 reforms, the average household saving rate in China was a mere two percent of household income. See Naughton, supra note 14, at 58. See Sachs \& Woo, supra note 7, at 28.

71. "Hard budget constraints" is the opposite of "soft budget constraints," a term coined by Hungarian economist Janos Kornai to refer to the utter lack of connection between a firm's earnings and expenditures. Even if a firm's expenditures chronically exceed its earnings, the firm's management does not undertake internal adjustments because the state will step in and provide the needed subsidies. See generally Janos Kornai, Economics of Shortage (1980); Vedat Milor, Changing Political Economies: An Introduction, in Changing Political ECONOMIES: PRIVATIZATION IN PostCOMMUNist AND ReFORMING COMMUNist STATES 6, 20 n.17 (Vedat Milor ed., 1994).

72. Pradumna B. Rana \& Wilhelmina Paz, Economies in Transition: The Asian Experience, in FROM REFORM TO GROWTH, supra note 7, at 119, 127, 130.

73. See generally WORLD BANK, THE CHINESE ECONOMY: Fighting INFLATION, DEEPENING REFORMS (1996); see also Lee, supra note 64, at 185 (noting that within six years of market-based reforms, from 1978 to 1984 , China had an annual growth rate averaging $8.3 \%$ in real net material product).

74. Lee, supra note 64, at 190.

75. There are four categories of firms in the non-state sector: individually owned firms, foreigninvested firms (both of which are privately owned, subsumed under the categories of "private economy" and "individual economy"), TVEs (including urban and rural collectives), and state-owned enterprises. See generally WEI \& LIAN, supra note 50.

76. See Naughton, supra note 14 , at 58 . 
Among the emerging firms in the new, non-state sector, TVEs have demonstrated one of the most remarkable growth and output rates. ${ }^{77}$ Between 1981 and 1990, for example, TVE output grew at an average rate of twenty-nine percent per year while exports grew at an average rate of sixty-six percent per year. $^{78}$ The TVE sector has become the second largest in China's economy, producing, for example, an estimated thirty-three percent of coal, forty-nine percent of canned goods, and fifty percent of electric fans in China. ${ }^{79}$ Within the rural sector, TVEs account for three-quarters of rural industrial output, or more than one-quarter of the national total. ${ }^{80}$

Although TVEs are not private enterprises because they are deemed to be "collectively owned," they nonetheless operate in a market environment outside of the state plan, are not subsidized by the state, and are subjected to hard budget constraints. ${ }^{82}$ Even before reform, "[t]hey were run by local agencies with virtually no access to capital, they acquired inputs through informal channels, they had to sell outputs on local markets, and they set prices accordingly." ${ }^{\prime 3}$ As a result, TVEs behave like market-oriented producers in functioning market economies, with market-based inducements for entry and exit. ${ }^{84}$ Like other new firms in the non-state sector that operate within an institutional environment of not only market autonomy but also budget constraints, TVEs have had little choice but to exhibit market-oriented behavior.

It is clear that economic growth in China has come primarily from the nonstate sector. In 1978, seventy-eight percent of national industrial output derived from state-owned firms; by 1993, state firms accounted for only forty-three percent of such output and non-state firms fifty-seven percent. ${ }^{85}$ Between 1978 and 1993, the share of state-sector employment also declined from seventy-five to less than sixty percent in the urban areas and from sixty to thirty percent in the

77. See Hong Kong's Economy Safe in China's Hands, S. CHINA Morning Post, Jan. 12, 1993, at 14, available in LEXIS, News Library, SCHINA File.

78. See Weitzman \& XU, supra note 16, at 9; see also JeAn C. OI, STATE AND PEASANT IN CONTEMPORARY CHINA 99 (1989).

79. See WEITZMAN \& XU, supra note 16 , at 9.

80. See Jiahua Che \& Yinqyi Qian, Institutional Environment, Community Government, and Corporate Governance: Understanding China's Township-Village Enterprises, 14 J.L. ECON. \& ORG. 1 (1998).

81. All members of the community-either a township or a village-are nominal owners while the community itself is considered the de facto owner. See WEITZMAN \& XU, supra note 16, at 11; see also Che \& Qian, supra note 80, at 1 ("TVEs are neither state-owned enterprises, cooperatives (such as labor-managed firms in Yugoslavia and workers cooperatives in Mondragon, Spain), nor private enterprises .... TVEs are best characterized as community enterprises with a governance structure in which the community government has control.").

82. See STEINFELD, supra note 59, at 12 .

83. Id. at 13.

84. See generally William A. Byrd, Entrepreneurship, Capital, and Ownership, in CHINA'S RURAL INDUSTRY 198-207 (William A. Byrd \& Lin Qingsong eds., 1990).

85. See Statistical YeARboOK OF CHINA 373-75 (1994), cited in Che \& Qian, supra note 80, at 30; see also Sir Alec Cairncross \& Cyril Z. Lin, The Private Sector That is Driving China, FIN. TIMES, Jan. 8, 1993, at 13; Gong, supra note 33, at 31. 
rural areas. ${ }^{86}$ Besides creating an economically dynamic non-state sector and a shrinking state sector, ${ }^{87}$ China also achieved economic growth at an average annual rate of ten percent ${ }^{88}$ as well as an unprecedented increase in foreign trade, ${ }^{89}$ with exports as a portion of GNP rising from approximately five percent in 1978 to almost twenty percent in $1991 .^{90}$

Despite its dwindling significance in both output and growth when compared to its non-state counterpart, the state sector remains remarkably large, a continuing albatross on the state. China currently has more than 200 million people employed in its 340,000 state owned enterprises, which account for thirty-four percent of the country's total industrial output, fifty-seven percent of its total fixed asset investment, and more than one-third of its GDP. ${ }^{91}$ At the beginning of reform in 1978, the state sector employed seventy-eight percent of the urban workforce, and by 1995, after almost twenty years of restructuring, it still employed a hefty seventy percent. ${ }^{92}$ According to an official 1994 report, the top 1,000 largest state enterprises, ${ }^{93}$ directly supervised by the central government, still comprise the bulk of the country's heavy, capital-intensive industry. ${ }^{94}$ Unlike the medium and small state firms that have been increasingly edged out by non-state enterprises and have therefore experienced a significant decline in state-sector output share, ${ }^{95}$ these large state firms still monopolize

86. See StATistical YeArbook OF CHINA, supra note 85, at 373-75, cited in Che \& Qian, supra note 80 , at 30 .

87. As a result, the Constitution was revised in 1988 to reaffirm the primacy of the state sector but also to recognize the emerging non-state economies. "The state permits the private sector of the economy to exist and develop within the limits prescribed by law. The private sector of the economy is a complement to the socialist public economy." XIANFA art. 11 (1982). The Asian Development Bank's 1994 Asian Development Report stated that state firms grew by $6.4 \%$ while TVEs grew by more than $40 \%$ and private enterprises as well as foreign-invested enterprises grew by more than $45 \%$. See Ramon Isberto, China Development: From Boom to Bust?, INTER PRESS SERVICE, May 11, 1994, available in LEXIS, ASIAPC Library, INPRES File.

88. See OVERHOLT, supra note 60, at 29. The growth rate declined to four percent in 1988 and 1989, moved up to seven percent in 1991 and to $12.8 \%$ in 1992. See id. at 29-30; see also Yingyi Qian \& Chenggang Xu, Why China's Economic Reforms Differ, 1 ECON. OF TrANSITION 135 (1993).

89. See OVERHOLT, supra note 60, at 27. By 1992, foreign trade rose to $\$ 166$ billion and exports increased from $\$ 14.8$ billion in 1979 to $\$ 85$ billion in 1992 .

90. See Qian \& Xu, supra note 88, at 135 .

91. See A Major Test for State Enterprise Reform, InsIDE CHINA MAINLAND (Inst. for Current China Studies, Taiwan), Jan. 1998, at 41, cited in Blumental, supra note 3, at 3. See generally WoRLD BANK, CHINA's MANAGEMENT OF ENTERPRISE ASSETS: THE STATE AS SHAREHOLDER (1997); Yuanzheng Cao et al., From Federalism, Chinese Style, to Privatization, Chinese STYLE 1 (Centre for Econ. Pol'y Res. Discussion Paper No. 1838, 1998).

92. See State Statistical Bureau 90 (1996), cited in Steinfeld, supra note 59, at 16.

93. Other figures place the number of large state firms at between 2,000 to 3,000. See STEINFELD, supra note 59 , at 11 .

94. Large state enterprises dominate natural monopoly industries such as telecommunications and railroads as well as other government monopoly industries such as airlines, banks, electricity, oil, and petrochemicals. See STATISTICAL YeARBOOK OF CHINA, supra note 85, at 388-91, cited in CAO ET AL., supra note 91, at 6.

95. Small and medium state enterprises, which together account for $95 \%$ of all state enterprises, are supervised by county, city, or provincial governments. Small and medium enterprises are in lighter, more competitive industries, such as electronics, textiles, and food processing, and other light manufacturing. See CAO ET AL., supra note 91, at 6 . It is only in these smaller state firms that there has been a 
heavy industry, even increasing its output from $41.5 \%$ of the total in 1978 to $43.6 \%$ in $1991 .^{96}$ Plagued by poor management, outright corruption, and social welfare-type obligations, ${ }^{97}$ many are ailing. Approximately fifty percent of state enterprises, according to official Chinese figures, operated at a loss in the first half of 1995, and forty-seven percent operated at a loss in the first threequarters of $1997 .^{98}$ Yet, until a national system of medical care and other social insurance is instituted, the government has been reluctant, for social, economic, and political reasons, ${ }^{99}$ to pursue full state-sector privatization. This may explain why the government began its state-sector reform, not by privatizing the state sector, but by implementing alternative strategies such as property-rights reform and governmental decentralization as part of a general move to separate the state from the management of the firm. ${ }^{100}$

\section{THE STATE SECTOR: STATE-ENTERPRISE REFORM WiTHOUT STATE-SECTOR PRIVATIZATION}

China, though a self-proclaimed socialist country, is slowly but increasingly becoming marketized. The market now governs the supply, demand, and prices of most goods and services where the plan once controlled quotas and prices. ${ }^{101}$

significant decline in state-sector output share. In 1978, urban small and medium state firms constituted $49.4 \%$ of total output; in 1985, 38.3\%; and in 1991, 25.2\%. See NAUGHTON, supra note 69, at 164 .

96. See NAUGHTON, supra note 69, at 164.

97. Under communism, state enterprises have traditionally been responsible for providing workers with comprehensive "cradle to grave" benefit packages such as pensions, subsidized housing, medical care, child care, food, and recreation. See NICHOLAS D. KRISTOF \& SHERYL WUdUNN, CHINA WAKes: THE StRuggle FOR THE SOUl OF A Rising Power 310 (1995); see also Joseph Kahn, Welfare Wanes: Holes in China's Safety Net Open Way for Providers, AsIan WALl ST. J., Feb. 2, 1998, at 1. As remarked by Wang Shiyuan, then Secretary General of China's State Commission for Restructuring the Economic Systems, "[o]nly when the social security system is established and perfected can enterprise reform be further deepened and a system realized in which efficient enterprises prosper and inefficient ones fail." Paul Blustein, Can Half-Reformed China Last? Hybrid Economy is neither Socialist nor Capitalist, WASH. POST, Aug. 29, 1993, at A27.

98. See Pamela Yatska, No Soft Landing, FAR E. ECON. ReV., Nov. 13, 1997, at 62; see also Central InTElligence Agency, APLA No. 97-10008, ChinA's ECONOMY IN 1995-97, 28 (1997), cited in Blumental, supra note 3, at 210.

99. See generally Gregory Fossedal, Enlist the Masses to Solve China's Dilemma, ASIAN WALL ST. J., Feb. 26, 1998, at 10 (more than 500,000 workers protested in 1997 when state enterprises "paid" their employees with IOUs); Jasper Becker, Unpaid Miners Blocking Rail Lines, S. CHINA MoRNING PosT, Mar. 10, 1998, at 8, available in LEXIS, News Library, SCHINA File (social unrest and workers' protest threatened government); Patrick Tyler, Overhaul of China's State Industry at a Standstill, N.Y. TIMES, Dec. 16, 1994, at A12 (workers' threat of rioting when a large state-owned knitting mill laid off 2,000 workers as part of a restructuring plan to bring the factory out of insolvency).

100. Some authors who have written about privatization generally have also attempted to move the privatization debate from what they consider to be "the ideological ground of private versus public to the more pragmatic ground of managerial behavior and accountability." See John B. Goodman \& Gary W. Loveman, Does Privatization Serve the Public Interest?, HARV. Bus. REv., Nov.-Dec. 1991, at 26, 28.

101. See NAUGHTON, supra note 69 , at 289-91. Prices have been freed for about $95 \%$ of consumer goods and $85 \%$ of industrial inputs, although the government could intervene periodically in the pricing of daily necessities, basic urban services, and key commodities. See People's Republic of China: Key Economic Indicators (visited Nov. 12, 1999) < http://www.mac.doc. gov:80/tcc/data/commerce_html/ 
To bring its state enterprises further within the market's orbit without privatizing their ownership structure, China created a comprehensive legal framework aimed at transforming state-run enterprises into merely state-owned ones, separating the government's ownership of an enterprise from its management and administration. ${ }^{102}$ In a move aimed at emulating the success of China's rural reforms, the Party Central Committee declared in its 1984 "Decision on Reform of the Economic Structure" various levels will, in principle, not manage or operate enterprises directly," ${ }^{104}$ signifying the government's recognition of an enterprise as a "legal person" separate from the government department in charge. ${ }^{105}$ Pursuant to a parallel

countries/Countries/China/country/Reports/1988/KeyEconomic.html>. For example, to promote development in the western part of China, the government relaxed price controls on rail transportation, airfare, automobile manufacturing, pharmaceuticals, and tourism for the region. See SDPC Adopts Pricing Policy to Promote Western China Development, ChinaOnline, Sept. 6, 2000, available in LEXIS, News Library. It has also lifted price controls on natural gas. See China to Lift Control on Natural Gas, ASIA PULSE, Aug. 18, 2000, available in LEXIS, News Library. In early 1998, grain prices were freed, but later that year-after China's state grain companies had lost more than 100 billion yuan competing with prices set by private enterprises-private grain dealers were prohibited from doing wholesale business and price control was re-instituted. See New Grain Distribution System Working in China, Xinhua News Agency, Nov. 22, 1998; Chinese Premier Tells State Grain Procurers to Compete With Private Trade, BBC, May 31, 1998.

The issue of which commodities and industries are to be subjected to price regulation and economic plan is first settled on the state-wide level and then at the provincial level, where each province can designate additional commodities or industries as essential and subject them to the province's own economic plan. For example, on the state level, China regulates such commodities as meat, sugar, and vegetables as well as public services, new technology sectors, industries related to state security, banking, and insurance. See Time to Fix SOE Distribution, CHINA DAILy, Oct. 28, 1999, at 4; China: Text of Chinese Communist Party Decision on State-Owned Enterprises, BBC, WORLDWIDE MONITORING Sep. 27, 1999; No Privatization for State Enterprises, BBC, Sept. 27, 1999; China to Improve Essential Commodity Distribution System, ASIA PULSE, Apr. 26, 1999. Conversely, such major industries as coal, machine-building, electronics, and textiles are not subject to the state-wide control. See SOE Reform Guidelines Restated, CHINA DAILY, Apr. 21, 1998, at 4. However, these industries could be controlled on a local level. For example, Beijing, Tianjin, and Hebei Provinces considered chemicals, building materials, metallurgy, and machine building essential enough to be regulated by the provinces' economic plans. Hebei Province Decides on Pillar Industries up to 2010, BBC, WORLDWIDE MONITORING, Jan. 12, 1998.

102. See NAtalie Lichtenstein, Enterprise Reform in China: The Evolving Legal FrAMEWORK 5 (World Bank Pol'y Res. Working Paper No. 1198, 1993).

103. Decision of the Central Committee of the Communist Party of China on Reform of the Economic Structure, translated in BEIJING REV., Oct. 29, 1984, at I.

104. Id. at X.

105. "An enterprise shall obtain the status of a legal person in accordance with the law and shall bear civil liability for property which the State has authorized it to operate and manage." Law of the People's Republic of China on Industrial Enterprises Owned by the Whole People art. 2 (1988), reprinted and translated in CHINA L. FOR. BUS. (CCH Austl.) 13-534 [hereinafter Enterprise Law]. Article 2 granted managers the rights and responsibilities of management. Article 14 prohibited the enterprise's departments in charge from interfering with the management of the enterprise. The rights provided by the Enterprise Law, however, are subject to "regulations of the State Council." Enterprise Law, chs. III, VI. Even before the passage of the Enterprise Law in 1988, the Economic Contract Law had referred to state-owned enterprises as "legal persons." In 1987, the General Principles of Civil Law defined a legal person as an organization with the legal capacity to enjoy civil rights and the competence to perform civil duties as well as to bear civil liability. See General Principles of Civil Law of the People's Republic of China art. 48, translated in 2 THE LAWS OF THE PEOPLE'S REPUBLIC OF CHINA 225 (1987). 
plan modeled after the rural "responsibility system," 106 state enterprises, as separate legal persons, were granted a degree of autonomy and allowed to retain their after-tax profits ${ }^{107}$ to give managers the incentive to increase their companies' competitiveness and profits. As I develop further below, however, reform measures such as managerial decentralization and even state-sector privatization itself, undertaken without the necessary, key institutional mechanisms of a true market economy, will not only fail to induce market and competitive behavior, but also produce the reverse of what was intended: predatory and rent-seeking behavior ${ }^{108}$ by economic entities that are newly autonomous, yet dangerously unmonitored by any meaningful system of governance.

To separate the firm from the state and to create opportunities and incentives for the firm, responsibility contracts have been instituted at all levels of the production and distribution chain, "between the state and enterprises ... between central and local authorities, between localities, between local authorities at various levels and between an enterprise and its staff and workers." ${ }^{109}$ Managers enter into contracts enumerating production targets to be met within a specified period of time. ${ }^{110}$ Once the targeted performance goals have been met, the enterprise is allowed to retain its excess profit for use in any way its management deems necessary, giving management certain rights over production, marketing, labor, procurement, investment, and asset disposition. ${ }^{111}$

In theory, then, state agencies are expected to concentrate on the general implementation of their governmental functions and not on the micromanagement of firms. As part of the decision to shift authority downward, local agencies themselves are supposed to rely on a local tax base and not on fiscal subsidies from the central government. ${ }^{112}$ Authority and opportunity are dispersed downward, from a once unified and monolithic source within the command economy to disaggregated constituent entities exhorted to act competitively and commercially. ${ }^{113}$

Consistent with its rural reform plan initiated ten years earlier, the government's state enterprise reform also involved the institution of a dual-track pric-

106. See supra notes $60-73$ and accompanying text.

107. See Decision of the Central Committee, supra note 103, at XII.

108. Rent-seeking behavior is behavior aimed at extracting earnings without any corresponding contribution towards the production of activities necessary to generate those earnings.

109. Observe Economic Laws, Speed Up Four Modernizations, XINHUA Gen. Overseas News SERVICE, Oct. 16, 1978, available in LEXIS, News Library, XINHUA File.

110. See Andrew X. Qian, Riding Two Horses: Corporatizing Enterprises and the Emerging Securities Regulatory Regime in China, 12 UCLA PAC. BASIN L.J. 62, 73 (1993).

111. See Rules on Transforming Management of State Enterprises, ch. II, arts. 6-22 (1992), Gazette of the State Council of the People's Republic of China (1992), translated in BBC SUMMARY OF WORLD BROADCASTS, July 29, 1992, available in LEXIS, World Library, BBCSWB File.

112. Pursuant to a system of fiscal contracting between the central and local government, the latter is given the right to collect and keep tax revenues, which in turn motivates it to promote local businesses such as TVEs. See OI, supra note 78, at 99-102; see also Andrew G. Walder, Corporate Organization and Local Government Property Rights in China, in CHANGING POLITICAL ECONOMIES: PRIVATIZATION IN POST-COMMUNIST AND REFORMING COMMUNIST STATES, supra note 71, at 53.

113. See generally STEINFELD, supra note 59, at 45-77. 
ing system within the state sector itself. Goods produced by state firms had to be sold at low prices to state agencies on the plan, but above-quota surplus could be sold at higher prices on the open market. ${ }^{114}$ The two-track pricing system was important for two reasons. First, it exposed state enterprises to market processes and, together with the system of managerial incentives described above, was instrumental in encouraging some firms to re-orient themselves toward greater productivity and efficiency. Second, it allowed state firms to interact with non-state firms, while competitive, profit-minded state enterprises sought to streamline and economize by subcontracting with more efficient nonstate businesses. ${ }^{115}$ The dual-track pricing system, in addition to the increasingly market-oriented nature of other spheres of the economy, meant that state enterprises-as legal entities separate from their departments in charge-had to learn to do more than simply navigate the bureaucratic channels for subsidies and quotas. ${ }^{116}$

Basic data compiled from 1978 to 1988 revealed that the gross output value of state enterprises increased from 342.1 billion yuan in 1978 to 1.35 trillion yuan in $1988 .{ }^{117}$ The total factor of productivity in state-owned industry also increased during the $1980 \mathrm{~s}$ at an annual average of $2.4 \% .{ }^{118}$ However, despite this apparent increase in productivity ${ }^{119}$ and years of market reforms, remarkably little has changed in the environment in which state firms operate, at least in ways that would cause state firms to change their behavior significantly. In fact, the very market-based reforms adopted to alter the economic behavior of state actors-decentralization and delegation of independent fiscal responsibilities from the state to the enterprise on the one hand, and greater managerial autonomy and incentivization on the other-often have had unintended consequences. Decentralization has broken up the command economy, as it indeed was intended to do, but it also has resulted in a disaggregated state consisting of numerous decentralized agencies and departments from various central, regional, and local ministries and their respective branches, each eager to exercise

114. See id. at 181-87.

115. See Naughton, supra note 14 , at 53.

116. Even large state enterprises such as China's largest tractor manufacturing company, for example, had to experiment with new and innovative ways to increase its market share:

"'to improve the quality of its products as well as its marketing and publicity techniques in a

bid to offset ... sluggish domestic sales .... The Luoyang tractor complex had been forced to sacrifice more than half of its profits in trying discounts, lotteries and free delivery of goods to boost sales."”

Thomas G. Rawski, Progress Without Privatization: The Reform of China's State Industries, in Changing Political ECONOMIEs: PRIVATIZATION IN POST-COMMUnist AND ReForming COMMUNIST STATES, supra note 71, at 39 (quoting Anming Gao, Giant Tractor Maker Plagued by Slow Sales, CHINA DAILY, May 28, 1991, at 4).

117. See Rawski, supra note 116 , at 30.

118. See Walder, supra note 112 , at 60.

119. To what extent this increase in productivity is mere "paper" profit is unknown, due to the extreme unreliability of financial information. See infra notes 146-156 and accompanying text. 
jurisdiction over the firm and correspondingly, "extractive authority over firm assets." $" 120$

Despite newly enacted regulations that prohibit the department in charge from managing or intervening in the management of the enterprise ${ }^{121}$ de facto control still exists, ${ }^{122}$ and even more troubling, precisely because of decentralization, control is exercised not just by one authority, but by multiple authorities, each with muddled claims of one sort or another against the firm, each acting "in the name of the state but serv[ing] their own parochial interests, employing powers of extraction perfected in earlier times." problem as having too many mothers-in-law. ${ }^{124}$ Various administrative agencies at both the national and local levels invested in an enterprise vie to exercise control over it, thereby subjecting the enterprise to overlapping and often conflicting vertical-usually one of the industrial administrative bodies attached to a central ministry-as well as horizontal-usually the local people's governments or their agencies-lines of authority. ${ }^{125}$

As a result, the agency/principal problem typical in any large firm ${ }^{126}$ is doubly compounded in an economy marked by informational uncertainties, unreliable accounting, and inconsistent financial data. How is the relevant governmental department that is presumably acting as "owner" able to monitor effectively the firm's managers if there is no reliable information about firm input, output, productivity, assets, or liability? ${ }^{127}$ Further, if there are multiple governmental entities exerting conflicting ownership claims to the firm's assets, and no one entity has unassailable authority over the firm, to which supposed "owner" is the firm's management accountable? Conversely, which agency among the many that assert the authority to interfere and to tax also is willing to accept the risk and responsibility that come with ownership? ${ }^{128}$

120. STEINFELD, supra note 59, at 6 . In this article, I have reevaluated my initial more positive assessment of China's second phase of economic restructuring: state-enterprise reform without statesector privatization. See Lan Cao, The Cat that Catches Mice: China's Challenge to the Dominant Privatization Model, 21 BROOKLYN J. INT'L L. 97, 144-51 (1995).

121. See supra notes 103-07 and accompanying text.

122. See STEINFELD, supra note 59, at 45; see also Anna M. Han, China's Company Law: Practicing Capitalism in a Transitional Economy, 5 PAC. RIM L. \& POL'Y J. 457, 489-90 (1996) (discussing the intervention at the firm level by various vertical and horizontal administrative authorities).

123. STEINFELD, supra note 59 , at 61 .

124. See Blumental, supra note 3, at 225, 224 n.108.

125. See Han, supra note 122, at 489; see also STEINFELD, supra note 59, at 91 (discussing the confusion at one state enterprise about which agency among the many governmental agencies might be the true "owner" of the company: the State Council, the State Planning Commission, the State Commission for Economics and Trade, or the various local governments of Lioaning Province or of Anshan City).

126. The problems derived from the separation of ownership and control have been revealed and analyzed in Adolf A. Berle \& GARdiner C. MEANS, THE MOdERn CORPORATION AND PRIVAte PROPERTY (1932).

127. For a discussion of the informational uncertainties in the Chinese economy, see STEINFELD, supra note 59 , at 45-77.

128. As an example, a firm studied by Professor Steinfeld entered into a responsibility contract with various entities on the state side-the State Commission for Economics and Trade, the State Commission on Economic Structure Reform, and the Ministry of Metallurgical Industry. See STEINFELD, supra note 59 , at 94 . 
The separation of the firm from the state has subjected the firm to varying forms of unchecked predatory behavior, such as inordinately high taxes and dubious fees and levies, ${ }^{129}$ even when the firm has no earned surplus and is barely staying afloat on short-term debt. ${ }^{130}$ Arbitrary and excessive taxation, in turn, has made it all the more difficult to discern between truly inefficient firms and firms that are efficient but overly taxed. Under such conditions of informational distortions, rent-seeking behavior becomes hard to trace and accountability difficult to impose. ${ }^{131}$ "As the state is driven out, the modicum of monitoring and control that existed under the old system virtually disappears, yet nothing arises in replacement," 132 particularly a regime of governance to alleviate the problems of informational distortion, imperfect monitoring, and opportunistic behavior.

In addition to decentralization at the state level, the implementation of measures at the firm level, aimed at separating the firm from the state, also has had unintended and detrimental consequences, because they were not supported by the proper institutional conditions, especially those related to banking and credit. ${ }^{133}$ In an overall environment that emphasizes liberation of the firm from the state and the manager from the plan without a corresponding regime of constraints, especially hard budget constraints, more autonomy for the enterprise and the manager has not always produced competitive, marketoriented behavior. Despite financial-sector reforms in which the government replaced direct subsidies to state enterprises with bank loans ${ }^{134}$ —again, in an ef-

None of the parties on the state side shared any risk with the firm, so they neither enforced the contract effectively nor adjusted it when it clearly seemed to be operating against the wellbeing of the firm. Second, since none of the state parties was held directly accountable, none defended [the firm] Angang against interference by other agencies not included in the contract.

Id.

129. See id. at 67,268 n. 21.

130. The firm's capital input is met through loans and sales that are neither truly loans nor sales. Loans can be "repaid" by rolling them over. Sales are recorded as having been completed even when the firm is not paid or is forced into providing credit. However, a sales tax is levied whether or not the firm is paid. Once sales taxes are paid, the firm owes additional levies and non-tax fees to various other municipal, provincial, and central agencies. See id. at 95.

131. Indeed, managers with a poor performance record may not fight state predation because excessive taxation may provide them with the excuse needed to mask their own inefficiencies. See id. at 67.

132. Id. at 75.

133. Some banking reform has occurred. In 1983, the government created a two-tiered, stateowned, but commercially oriented, banking system. The Industrial and Commercial Bank of China was separated from the People's Bank of China, with the former designated as a commercial lending operation and the latter continuing on as the country's central bank. See NAUGHTON, supra note 69, at 255. Still, the commercial banks are not truly commercial because they are subject to orders from the central authorities to make policy loans and to bail out politically important firms. See infra notes 141-44 and accompanying text. For an examination of banking-sector reform, see GANG YI, MONEY, BANKING, AND FINANCIAL MARKETS IN CHINA 27 (1994) (stating that the aim is to give "more freedom of operation and profit motives to specialized and other commercial banks, making them independent economic entities while macro monetary policy was controlled by the central bank").

134. For a general discussion of the switch from direct state subsidies to bank loans used to support ailing state enterprises, see generally HARRY G. BROADMAN, MEETING THE CHALlENGE OF ENTERPRISE REFORM (World Bank Discussion Paper No. 283, 1995). Because of the decline in the government's revenue due to the stagnation of its state sector, the government had fewer resources at 
fort to create some semblance of hard budget constraints on the relevant economic actors ${ }^{135}$ - capital, in the form of bank credit, continues to be lavished upon state enterprises at the request of the managers, regardless of whether the loans will be repaid. ${ }^{136}$ Not only has this shift been ineffective from a market perspective, and undermined by the absence of a functional regulatory regime, it is also a form of private subsidy borne by ordinary household depositors, many from the countryside of the South, to support ailing state firms in the cities of the North, causing a massive transfer of wealth from the rural to the urban sectors. ${ }^{137}$ Total bank loans measured on an annual basis grew from fifty percent of the GDP in 1978 to ninety percent in $1996,{ }^{138}$ with the majority of loans directed toward state-sector firms ${ }^{139}$ Nonperforming loans held and rolled over by state banks are estimated to be at more than 1.27 trillion renminbi or even higher. ${ }^{140}$ State-owned commercial banks, which are theoretically selfsupporting but in reality supported by the state, continue to provide credit to state firms on non-market terms, performing none of the functions associated with commercial lending, neither screening the borrowers for creditworthiness nor monitoring and enforcing the loans. ${ }^{141}$ In fact, banks are often directed by the central government to make non-commercial, policy-based loans to certain state firms, in which case the loans may be supported by the credit of the central

its disposal to bail out state firms. See Statistical Yearbook of China 22-23 (1996). At the same time, it was unwilling to run up a fiscal deficit and thus shifted the burden to the banking sector instead. See BROADMAN, supra, at 25; see also CAO ET AL., supra note 91, at 16 (describing how the Budget Law of 1995 prohibited the central government from "deficit financing its current account").

135. Under the old plan system, firms that received direct government subsidies had little incentive to maximize their capital allocation. Rather, their incentive was often to consume all of their annual allocation and to overestimate their future capital requirements, as capital came without cost. To alter this behavior, the government decided to make capital-allocation decisions on more market-oriented terms-by switching from direct government subsidies to bank loans. The rationale is that, rather than support state firms with subsidies that come from the central budget, interest-bearing loans, extended by the major state banks on quasi-commercial terms, would force the borrowers- the state firms-to ensure the efficient use of such loans.

136. See, e.g., Indira A.R. Lakshmanan, Wary Chinese Edge Into Capitalism, Boston GLOBE, Nov. 9, 1997, at A38; Greg Mastel, A China the World Could Bank On, WASH. Post, Dec. 29, 1997, at A17; Thomas G. Rawski, Is China Next?, Asian WALl ST. J., Jan. 23, 1998, at 8; see also STEINFELD, supra note 59, at 68-77; $c f$. CAO ET AL., supra note 91, at 17 (describing financial reforms as having had the effect of reducing local influence on credit allocation and increasing the hard budget constraints of state banks made to adopt international standards for bank assets and commercial-based lending).

137. See Liu Binyan \& Perry Link, A Great Leap Backward, N.Y. Times BoOK ReVIEW, Oct. 8, 1998, at 19 (reviewing He QINGLIAN, CHINA's PITFALL 1998); STEINFELD, supra note 59, at 22, 75, 96, 264 n.54.

138. See STEINFELD, supra note 59, at 19-20.

139. By 1995 , outstanding loans to the state industry was 3.36 trillion renminbi, which was $83 \%$ of all outstanding bank loans for that year. See STEINFELD, supra note 59, at 20.

140. See Henny Sender, Small Change, China's Banks Labour with the Baggage of Their Past, FAR E. ECON. ReV., Aug. 8, 1996, at 62; Craig S. Smith, China Scrambles to Avert Banking Crisis, WALL ST. J., Aug. 6, 1996, at A1.

141. See STEINFELD, supra note 59, at 71 ("Once [the banks] have made policy loans directed from above, bank officials have nothing to lose by simply loaning the rest of their available capital to the highest bidder, regardless of the bidder's creditworthiness."). For a contrary and more optimistic assessment of banking reform in China, see CAO ET AL., supra note 91, at 17 (arguing that the centralization of the central bank's operation and the restriction of the authority of the central bank's local branches to make independent loans have reduced the local government's influence over credit policy). 
bank itself, the People's Bank of China ("PBC"), based on lending quotas allocated by the PBC to regional banks nationwide. ${ }^{142}$ Banks may also be pressured by provincial and local government agencies into making loans to politically favored state enterprises, ${ }^{143}$ a problem that has grown even worse because of decentralization. ${ }^{144}$

Against a background of such broad, systemic distortions and ineffective signaling mechanisms, the government cannot easily shut down failing banks, because it cannot accurately determine whether bank losses are caused by the bank's own bad lending decisions or by non-commercial loans the banks were directed to make to state firms. In turn, those state firms that received loans at practically no cost have little incentive to ensure the productive use of capital. Instead, these firms engage recklessly in dubious inter-firm transactions and contribute to the growing problem of inter-enterprise-or "triangular" - debt, ${ }^{145}$ without fear of sustaining adverse consequences, precisely because there is no credible threat of bankruptcy or other market-induced incentives to exit in the event of enterprise failure. There is, in fact, no true threat of bankruptcy possible because the financial information required to assess a firm's viability is either not available or not reliable. Before the 1993 accounting reforms, for example, Chinese industrial enterprises used more than seventy different accounting methods. ${ }^{146}$ The cycle of soft budget constraints for both banks and firms, the web of triangular inter-firm debt, and the lack of standard or uniform accounting principles have made it increasingly difficult for decisionmakers to distinguish solvent firms from insolvent firms and failing banks from profitable banks. It is additionally difficult to determine whether a firm's financial loss is caused by endogenous factors, such as managerial inefficiencies and predation, or exogenous factors, such as industry-wide downturns, excessive taxation, or even a firm's high social welfare obligations. ${ }^{147}$ Given the high social costs of large-scale unemployment, the central government has opted for the more po-

142. See BROADMAN, supra note 134 , at 15 .

143. See STEINFELD, supra note 59, at 21.

144. See supra notes $133-43$ and accompanying text; see also infra notes 157-58 and accompanying text.

145. See generally Asian DeVelopment BAnK, People's Republic of China, TA No. 2271, STATE ENTERPRISE INSOLVENCY REFORM 132-35 (1996). Within the context of China, state firms may run up a high level of receivables - which may show as profit even though the customers do not pay-in effect extending credit to their customers, which are often other state firms. This process, in which one set of firms - the producers-allow transactions to pile up as unsettled and outstanding receivables while another set of firms-the purchasers-extract "loans" from the former by merely delaying payment, may result in a complex configuration of debt between firms and across sectors, between state firms and state banks. Since the beginning of reform, triangular debt has grown tremendously: By 1994, it reached an estimated 600 billion renminbi. See BROADMAN, supra note 134, at 16.

146. See Dwight Perkins, Completing China's Move to the Market, J. ECON. PERSPECTIVES, Spring 1994, at 23-46.

147. State firms are often saddled with the high costs involved in providing state workers with medical care, housing, and other worker benefits through enterprise funds, such as worker housing construction projects and worker bonuses. See Lee, supra note 64, at 194; see also STEINFELD, supra note 59, at 66. 
litically expedient, albeit economically disastrous, option of continued firm bailouts. ${ }^{148}$

In an environment characterized by a general lack of fiscal oversight, managerial autonomy often has meant managerial predation and resource misallocation. For example, responsibility contracts allowing managerial use of firm profits above the state quota have "created incentives at the managerial level for overproduction and reckless investment in plant capacity." ${ }^{149}$ The shift from compliance with plan output quotas to maximization of profit ${ }^{150}$ did force managers to make profit maximization a high-priority objective ${ }^{151}$ but it also compelled some to adopt practices that allow the firm to "show" profit, whether true or not. ${ }^{152}$ "Sales" are made to other firms, even if the latter are unable to pay, and managers are more willing to roll over bad debt than to write them off or even settle for less, because the latter options would result in an erosion of nominal recorded profits. ${ }^{153}$ Asset valuation is routinely inflated. Receivables and credits, whether recoverable or not, are recorded as if they were the equivalent of cash, and depreciation costs tend to be underestimated to assign a more respectable book value to assets with minimal market value. Within a context of soft loans and ambiguous accounting standards, fundamentally weak firms can nonetheless show profit and even expand, thereby drawing in even more workers, which, in turn, makes the firms too politically significant to be allowed to fail. Ironically, firms that show high profits, inflated or otherwise, are also those most susceptible to predatory taxes by the state and its multiple arms. ${ }^{154}$ Some firms have responded to state predation by adopting an octopuslike type of self defense-shooting ink and darkening the waters by creating confounding webs of subsidiary chains, enterprise groups, affiliated collectives, and private companies as a means of sheltering their assets from tax collectors. ${ }^{155}$ Tracking down assets buried within the bureaucratic channels of several hundred smaller units is more difficult than merely taxing one large enterprise. Additionally, collectives and private companies, until the 1994 tax law, were taxed at a lower rate than state firms. ${ }^{156}$

148. See STEINFELD, supra note 59, at 64 .

149. Id. at 6 .

150. Indeed, the 1993 accounting reforms were implemented so that managers could exercise greater control over firm assets, which meant that accounting standards had to reflect market-oriented objectives. Balance sheets produced under the new rules are expected to show firm assets, liabilities, and equity. See generally INTERNATIONAL BANK FOR RECONSTRUCTION AND DEV., CHINA'S MANAGEMENT OF ENTERPRISE ASSETS: THE STATE AS SHAREHOLDER 70 (1997).

151. For a positive assessment of this trend, see Gary H. Jefferson \& Thomas G. Rawski, Enterprise Reform in Chinese Industry, J. ECON. PERSPECTIVES, Spring 1994, at 47-70.

152. Some studies have found that Chinese managers seek to avoid predatory taxation by declaring losses and hiding profits. See generally Shaoguang Wang, The Rise of the Regions: Fiscal Reform and the Decline of Central State Capacity in China, in THE WANING OF THE COMMUNIST STATE: ECONOMIC ORIGINS OF POLITICAL DECLINE IN CHINA AND HuNGARY 87-113 (Andrew G. Walder ed., 1995).

153. See STEINFELD, supra note 59, at 107.

154. See id. at 113 .

155. See id. at $97-101$.

156. See id. at 99. 
Enterprise autonomy unconstrained by an effective system of governance has also led to "insider control" by managers who, sometimes in collusion with workers, engage in "enterprise asset stripping" and other actions at the expense of the state. ${ }^{157}$ During the first decade of reform, when a two-track pricing system was first instituted, in an illicit scheme popularly called "official turnaround," officials and managers procured commodities at the lower, controlled price for state enterprises within the planned economy and then "turned around" and sold the same commodities at a higher price on the non-state and private market. ${ }^{158}$ The frenzy to get rich, as proclaimed in the Party's slogan that "to get rich is glorious," 159 also led to the widespread use of public funds by insiders for personal speculation in such ventures as real estate and stock, with gains pocketed by the insiders and losses absorbed by the affiliated state firm. ${ }^{160}$ Transferring control downward from central to local to firm, without more, did not induce a behavioral change in the relevant economic actors, whether banks or firms. In fact, the opposite might be true under certain circumstances. For certain politically significant firms, such as those that once occupied the "commanding heights" of central planning and are themselves "cities within cities," the threat of economic failures and potentially large-scale layoffs might itself be a source of political strength, providing them with the leverage needed to extract additional loans from the state. ${ }^{162}$ Although the figures vary, it has been estimated that over the years, twenty percent of the government's annual revenues were siphoned into the more than sixty percent of the state-owned firms that lost money. ${ }^{163}$

China, in other words, still faces a political and economic crisis that has no simple solution. At the state level, governmental decentralization, ostensibly aimed at loosening the grip of the command economy, has exposed the firm to intervention by a wide array of state actors in vertical and horizontal chains of command. Within the firm itself, governmental decentralization, the downward transfer of rights, and the separation of the firm from the state have resulted in more autonomy for managers as intended, but they also set into motion a web

157. See generally Yinyi Qian, Enterprise Reform in China: Agency Problems and Political Control, 4 ECON. OF TRANSITION 427, 427-47 (1996).

158. See Binyan \& Link, supra note 137, at 20. Indeed, misuse of the dual price system was one of the factors that fueled popular resentment against the government and contributed to the Tiananmen Square demonstrations in 1989. See Clague, supra note 63, at 8 n.2.

159. Henry Chu, In March Toward Capitalism, China Has Avoided Russia's Path, L.A. TIMES, Sept. 16,1998 , at 4.

160. See Binyan \& Link, supra note 137, at 20.

161. Anshan Iron and Steel is one example, with a core business that consists of 140 different factories and employs 220,000 employees. In 1994, it had 110,000 retired workers for whom it still had to provide pensions, housing, and medical care. See STEINFELD, supra note 59, at 98.

162. See id. at 109.

163. See Orville Schell \& Todd Lappin, China Plays the Market, 1992 NATION 728; see also Xiao Yu, Backing for State Firms, S. CHINA MORNING Post, Nov. 7, 1994, at 8, available in LEXIS, News Library, SCHINA File (noting that in 1992, $\$ 7.82$ billion of China's state expenditures-excluding additional "soft loans"-were used to subsidize state firm losses). 
of causally linked and distorted incentives that are difficult to rectify because of the absence of internal and external controls.

After years of enterprise restructuring and reform that to this day fail to produce a general environment in which state firms systemically exhibit marketoriented behavior, China now is embarking on a more ideologically thorny path of reform aimed at transforming the very ownership framework of the state sector itself-that is, the conversion of state firms into shareholding companies and the sale of shares to private investors. Yet, as the next section of this article demonstrates, it is not enough simply to transfer some ownership rights to private entities. Such transfers must also be accompanied by (1) an internal governance regime to ensure that owners can adequately monitor managers, and that agents will in turn act in the interest of their principals; and (2) a set of $e x$ ternal governance mechanisms - such as strict accounting standards, hard budget constraints, financial disclosure requirements, or hostile takeovers and bankruptcy proceedings - to minimize the problem of imperfect information.

\section{$\mathrm{V}$}

\section{StATE ENTERPrise ReForm THROUgh StATE-SECTOR PRIVATIZATION}

Two overriding reasons motivated China to convert its state enterprises into shareholding companies and to establish a securities market: first, the chronic inability of state firms to maintain financial self-sufficiency and solvency; and second, the desire of the state to tap into a growing pool of private capital in the non-state sector wholly outside of its control. By establishing a shareholding system, the government can alleviate the problem of state-sector insolvency, while bringing the increasingly threatening reservoir of private capital within the perimeters of the government-controlled state sector. In other words, statesector privatization in China was motivated by a dearth of capital in the state sector and, equally important, by what the government considered to be an excess of capital in the non-state sector. As I analyze below, by ensuring that privatization will not strip the state of majority ownership in a state enterprise after its "privatization," private capital will be put to state use and subjected to state control under the euphemism of "corporatization" or "securitization." This can be compared to the situation in Russia and Eastern Europe, for example, where there was essentially little domestic private capital, as there was no viable non-state sector. There, the problem the state encountered was not too much private capital but rather, too little-in other words, how to sell assets to raise much needed capital to domestic buyers who had almost no capital. ${ }^{164}$

Over the years, the prosperity of the non-state sector allowed China's private citizens to save large amounts of money. With one of the highest annual

164. Many Eastern European countries opted for the politically appealing voucher system, which involves the free distribution of vouchers to citizens who can in turn exchange them for shares in the privatized enterprises. See supra note 46 and accompanying text. 
saving rates in the world - approximately thirty percent ${ }^{165}$ — private surplus capital at one point constituted approximately 1.3 trillion yuan or $\$ 260$ billion, ${ }^{166}$ although other sources put the amount at $\$ 310$ billion, ${ }^{167}$ with an estimated $\$ 200$ billion idle in the domestic banking system and another $\$ 100$ billion concealed outside the system, under mattresses, for example, by people distrustful of banks. ${ }^{168}$ This amount is even more startling and-from the government's point of view- is politically threatening when compared to the value of state-held assets, which totaled about $\$ 240$ billion. ${ }^{169}$

Despite China's high savings rate, "[s]aving remains an unattractive prospect because the bank interest rates are typically low (often lower than the rate of inflation)." ${ }^{170}$ From the perspective of the individual saver, then, the prospect of receiving much higher returns through securities investment is an appealing one. From the perspective of the government, establishing a shareholding system to finance public debt and to coax private savings into an arena susceptible to the control of the state is equally appealing. At the same time, with increasing concerns that surplus capital also could spark inflationary spending, the government believes that securities also can be used as a strategy for cooling a possibly overheated economy, "as money could be steered toward investment rather than consumer spending."

Like its other market-oriented measures, China's conversion of private savings into investment capital must be contained within the perimeters of market socialism. Thus, capital extracted from Chinese personal savings was converted initially into debt instruments that do not threaten socialist ownership and later into limited minority interests that do not threaten the state's role as majority shareholder of state enterprises, ${ }^{172}$ resulting in the wrong sort of regulation: po-

165. See Schell \& Lappin, supra note 163 , at 730 . Other sources put the savings rate at about $39 \%$. See, e.g., Money and Banking: 11.4 Securities and Bond Markets, CHINA HAND, Oct. 1, 1993, available in LEXIS, Asiapc Library, CHINA File [hereinafter 11.4 Securities].

166. See Black Market Forex Deals Bleed Economy, S. ChInA Morning Post, Dec. 28, 1993, at 2, available in LEXIS, News File; Schell \& Lappin, supra note 163, at 730.

167. See Business Briefing: China, FAR E. ECON. REV., Apr. 1, 1993, at 83, available in 1993 WL FEER; see also STATISTICAL YEARBOOK OF CHINA, supra note 85 (estimating household bank deposits and financial assets for 1993 at about 1 trillion yuan and 2 trillion yuan, respectively, versus the 3 trillion yuan estimated for total state assets.)

168. See China, EUROMONEY: HANDBOOK OF WORLD ECONOMIES AND INVESTMENT OpPORTUNitiES, Sept. 1992, at 121, 124 (Supp.); JOHN R. GuARDiAnO, EXPLODING THE Myths About ECONOMIC ReFORM IN Russia (Heritage Found. Report No. 930, Mar. 9, 1993).

169. See Business Briefing, supra note 167, at 83.

170. 11.4 Securities, supra note 165.

171. Paul Schroeder, Rebuilding China's Securities Markets, CHINA Bus. REV., May-June 1991, at 20, 21; see also Gong, supra note 33, at 36.

172. Scholars, practitioners, and reformers in China defended the securities system as being compatible with and complementary to socialism. "The shareholding system has emerged under the capitalist system but it is not the exclusive right of capitalism. Rather, it is the product of the socialization and commercialization of production. It may exist under the capitalist system but it can also exist under the socialist system and serve socialism." Qian, supra note 110, at 82 (quoting Xiao Zuoji, Shixin Shehui Zhuyi Gongyouzhi De Xinshi [On the Forms of Realizing Socialist Ownership], 2 JINGJI YANJIU 38 (1992)). 
litical regulation to serve the state's desire to maintain control, rather than the necessary market regulation to transform state actors into market actors.

As I argue below, the securities system has been grossly distorted not only by the state's insistence on retaining supermajority shareholder status, but also by its unwillingness to allow private enterprises access to the securities market itself. Unlike the first stage of reform, in which sound economic reasons justified the deferral of state-sector privatization in favor of first creating a private or non-state sector, the current stage of state-sector privatization reform reflects less rational economic policy than crass political manipulation. As I have argued throughout, China's failure at state-sector reform-like Russia's statesector privatization efforts-has been caused by the absence of an institutional framework necessary to ensure market-oriented behavior and reduce transaction costs. Thus, in its current phase of reform, in which it finally decides to commit resources to the creation of property rights by privatizing its state enterprises, China's failure to create the regulatory and governance regime needed to make property rights work has, in fact, resulted in a circular replication of the problem it is attempting to remedy in the first place: the very absence of property rights itself. In other words, China's failure to establish in the state sector a regulatory framework for its newly instituted market and privateproperty regime has led to principal/agency problems that have prevented "owners" from acting as true owners. Additionally, transaction-cost problems have prevented a reallocation of property rights - to the minimal extent that property rights can be said to exist at all-to the highest-valued use. The argument I set forth below is that even a minimalist, Delaware-type model of corporate governance, if adopted, would be desirable and highly effective in transforming the behavior of privatized state-sector enterprises.

In the mid-1980s, the central government's decision to restrict the money supply forced many state enterprises, especially those not politically favored or connected, to find new ways to finance themselves. At the beginning, China's securities issuance was limited strictly to internal bonds such as workers' bonus or incentive shares. The rationale was well expressed by one worker in the state-run People's Bank of China: "Most of our shareholders will be workers. There is no contradiction." 173

The government also relied on government-issued bonds to subsidize its own capital shortages. ${ }^{174}$ Debt instruments void of equity interests allowed the government to raise needed capital without undermining state ownership and control of state enterprises. After more than thirty years, the issuance of longterm state treasury bonds in 1981 signified the reestablishment of China's

Liu Hongru, Deputy Director of the State Commission for Restructuring the Economy, stated, "We are a socialist country, and we must hold fast to public ownership of assets, and to the principle of combining a market economy and a planned economy. Under these conditions we will create securities markets." Juliet Sychrava, China: Marches to a Changing Tune, EurOMONEY, Aug. 1, 1990, at 50.

173. Peter Goodspeed, "Capitalist Oppression" is Back as Shanghai Market Re-Opens, TORONTO STAR, Dec. 16, 1990, at F1.

174. See OVERHOLT, supra note 60, at 151-56. 
securities market. ${ }^{175}$ By the end of the 1980s, "the forms of state-issued bonds had proliferated: they included government bonds, treasury bonds, special project bonds, and value-guaranteed bonds with interest rates indexed to inflation," ${ }^{176}$ eventually leading to the emergence in 1988 of secondary market trading. ${ }^{177}$ From 1981 to 1988 , bonds alone were the driving force behind the securities market. ${ }^{178}$ Indeed, the State Council promulgated a notice in 1987 that ordered that stocks may be issued only by a select number of approved collective enterprises and that state enterprises may not issue stock, only bonds and other debt securities. ${ }^{179}$

The relative success of bonds as a fundraising device paved the way for the subsequent implementation by the government of a 1984 World Bank proposal that a firm's "assets... be divided into shares and owned by several government departments." ${ }^{800}$ Under this scheme, state enterprises are converted into shareholding companies whose shares are cross-held by other state enterprises with sufficient capital surplus to experiment in capital investment. In guidelines issued by the State Commission for Restructuring the Economic System, the government has most vigorously embraced this form of "legal person" shareholding, whereby shares of one state firm are held by other state firms. ${ }^{181}$

China's experiment with shareholding has surpassed that proposed by the World Bank to permit, for example, even private equity interests in privatized state enterprises. Under the 1992 Opinion on Standards for Companies Limited By Shares, ${ }^{182}$ issued pursuant to the Share Enterprise Trial Measures, ${ }^{183}$ although a company may issue common or preferred shares that are similar to those issued in the United States, its shares must be additionally divided into various categories of shares based on the shareholder's status: state shares, legal

175. See Christian Bauta, China: Investment Banking, Industry Sector Analysis (visited Oct. 12, 2000) <http://www. tradeport.org/ts/countries/china/isa/isar0068.html $>$.

176. OVERHOLT, supra note 60 , at 152.

177. See id. at 152, 154. Experimenting markets for bond trading were established in seven, and later, 54 cities. By 1990, a nationwide, computerized bond-trading network, the Securities Trading Automated Quotations Systems ("STAQS") was opened. See id. at 155.

178. See Qian, supra note 110, at $66 \mathrm{n} .15$.

179. See Jia Zhao \& Li Qian, Trading Stocks in China: Development, Regulation, Issues and Prospects, E. ASIAN EXECUTIVE REP., June 15, 1992, at 8; see also Fang Liufang, China's Corporatization Experiment, 5 DuKE J. COMP. \& INT'L L. 149, 156 n.16 (1995) (describing a State Council administrative order that prohibited state enterprises from issuing shares to the public and specifying which state organization shall be responsible for the supervision of share issuance: the Head Office of the People's Bank of China for issuance by state enterprises of more than 30 million shares (in renminbi) and the local branch of the People's Bank for the issuance of less).

180. Qian, supra note 110 , at 75.

181. See Fang, supra note 179 , at 156.

182. See Opinion on Standards for Companies Limited by Shares, reprinted and translated in 3 ChinA L. For Bus.: Bus. REg. (CCH Austl.) (issued on May 15, 1992 by the State Commission for Restructuring the Economic System).

183. Trial Measures on Share-Formulated Enterprises, 2 CHINA L. FOR FOREIGN BuS.: BuS. REG. (CCH Austl.), II 13-570 (issued on May 15, 1992, by the State Commission for Restructuring the Economic System, the State Planning Commission, the Ministry of Finance, the People's Bank of China and the State Production Office). 
person shares, and individual shares, ${ }^{184}$ with the last category further divided into A shares, which can be bought by Chinese citizens in local currency, and B shares, which can be bought only by foreign parties in foreign currency. ${ }^{185}$ These classifications have resulted, as I argue below, in excessive state control of the market. ${ }^{186}$ The government has sought to retain political control in two primary ways: first, in the listing procedures employed to restrict the issuance of shares, and second, in the trading regulations designed to limit the types of shares deemed tradeable.

Until 2000, the central government, through the China Securities Regulatory Commission ("CSRC"), the agency responsible for the execution and enforcement of policies created by the China Securities Commission, still set an annual capital quota for the total value of shares that can be issued. ${ }^{187}$ Thus, an enterprise not only had to apply for a public offering and satisfy certain standard criteria-such as those relating to financial auditing, disclosure of company assets, and underwriting contracts ${ }^{188}$ — but also had to apply for an assignment of a share quota. The conditions concerning the issuance of quotas, however, were not within the control or purview of the enterprise because they were a reflection of and dependent on the political process that determined how quotas were to be allocated-how much and to which local governments and central governmental organs. ${ }^{189}$

Once a quota was established, each province was allocated its portion of the total allowance, and the province made its own selection ${ }^{190}$ among local compa-

184. See Opinion, supra note 182 , arts. $23,24,29$. The provinces had also enacted their own measures dealing with the issuance and trading of shares, which utilize a similar system of share classification. See, e.g., Provisional Measures of Shenzhen Municipality for Administration of the Issue and Trading of Shares, reprinted in 14 E. ASIAN EXEC. REP., Sept. 15, 1992, at 21 (effective June 15, 1991). See also Article 33 (stating that shares shall be divided into state, legal person, and individual shares and that the state shall retain a controlling interest in a state firm); Article 45 (stating that state shares are not transferable); Nicholas C. Howson, China's Company Law: One Step Forward, Two Steps Back? A Modest Complaint, 11 Colum. J. AsIAN. L. 127, 158 \& nn.112-13.

185. See infra note 199 and accompanying text.

186. See infra notes $220-235$ and accompanying text.

187. See Fang, supra note 179, at 177-81; see also Bauta, supra note 175. After this article was completed and while it was prepared for final publication, the government announced that "a selection process based on legislation and practice overseas would replace the quota system." B-Share Market Enjoys Reform and Measured Revival, INT'L BRIEFING, Aug. 3, 2000; see Winston Yau \& Eric Ng, Beijing Ready to Drop Curbs on Share Issues, S. CHINA MORNING POST, July 6, 2000, at 1, available in LEXIS, News Library, SCHINA File ("[R]emoval of the share-issuing quota meant that there would be no ceiling on the amount of shares-A and B-to be issued every year, so more fund-raising exercises could take place for as long as the market could accept them."); China Fully Prepared for a "Second Stock Market,” BBC WORLDWIDE MONITORING, Apr. 17, 2000.

188. See Fang, supra note 179, at 181-82 (citations omitted).

189. See id. at $183-85$.

190. There have been complaints that the CSRC has too much power and that it is not just approving but selecting the companies which are then allowed to list. See Henny Sender, Shareholder-Rights Case Points Up CSRC's Power, Asian WALl ST. J., July 23, 1999, at 13 (A Hong Kong attorney complained that " [the CSRC] say they are just approving, but in fact they are selecting the companies which are allowed to list."”); Ian Johnson, China Pulls Out All Stops to Coax Growth, ASIAN WALL ST. J., July 6, 1999, at 1 ("Despite hints that rules will change, government bureaucrats still select companies for listing."); Anthony Zaloom \& Liu Hongchuan, A Legal Framework for Securities: Chinese Securities Law Finally Takes a Step Forward, ChINA BUS. REV. May 1, 1999, at 26, 28 ("[A] company 
nies that applied for share issuance-based on the size of its shares quota and on the sectoral or industrial significance of the company applying. ${ }^{191}$ Whether the official quota system did, in fact, control and determine the amount of share issuance is itself a separate matter, however. For example, although the total issuance quota for the country was one billion renminbi in 1992, one hundred companies in some of the major provinces alone were permitted to issue 8.98 billion renminbi worth of shares to the public. ${ }^{192}$ The system thus appeared arbitrary and capricious, and there was the sense that the state-controlled and statesupervised selection process furthered less the economic interests of the investing public than the vested political interests of the well-connected firms or those in sectors favored and promoted by the government. ${ }^{193}$ While it is too early to know whether the government will, in practice, allow the issuance of shares to be determined by market considerations rather than the strictures, formal or informal, of a state plan, its decision to eliminate share quotas does show that it recognizes the need to minimize the government's involvement in the process of share issuance and the appearance of political favoritism.

Besides favoring certain state firms over other less politically appealing ones, the securities system also favors state firms in general over private firms, even though the government amended the language in the Constitution in 1999 from "[t]he private sector complements the socialist public ownership system" to " $\mathrm{t}]$ he individual, private and other non-state sectors are an important component of the socialist market economy." ${ }^{194}$ Because the government no longer directly subsidizes state firms, its aim is to use the stock markets as a fundraising vehicle for state enterprises. Private firms, therefore, are essentially locked out of the stock market: ${ }^{195}$ "Official policy is to use the stock market mainly to raise money for state companies."

seeking a listing must first be selected by provincial or ministerial offices that must fill yearly, central government-set quotas").

191. See Bauta, supra note 175; see also Securities: Doubts Grow About Command-Style Controls, S. CHINA MornING POST, Nov. 12, 1998, at 2, available in LEXIS, News Library, SCHINA File (discussing the politicized nature of the quota system).

192. See Fang, supra note 179, at 196.

193. See Bauta, supra note 175; see also China: Individual Businesses Protected, CHINA DAILY, Jan. 7, 2000, available in LEXIS, News Library.

194. James Kynge, Beijing Fillips for Dynamic Private Sector, FIn. TIMES, Feb. 4, 1999, at 7; see also China: NPC to Consider Drafting Private Protection Law, CHINA BUS. INFO. NETwORK, Apr. 5, 1999.

195. See Chinese Private Enterprises Sweep Up Listed Firms, ChInA BuS. INFO. NeTwork, June 17, 1999, available in LEXIS, News Library; Mark O'Neill, New Hope Boosts War Chest for Asian Feedgrain Battle, S. CHINA MORNING POST, Mar. 13, 1998, at 4, available in LEXIS, News Library, SCHINA File [hereinafter O'Neill, War Chest] (discussing the debate over whether private companies should have more access to capital, through bank finance and stock market listings); Mark O'Neill, Private Companies Gear Up for Easing of Foreign, Local Listing, S. CHINA MORNING POST, Aug. 3, 1998, at 3, available in LEXIS, News Library, SCHINA File [hereinafter O'Neill, Private War Companies Gear Up].

196. O'Neill, War Chest, supra note 195, at 4. Liu Ji, Vice President of the Chinese Academy of Social Sciences, for example, opposes listing on the public exchanges by family-owned firms, because it would give public money to single families. See id.; see also Dexter Robert \& Mark L. Clifford, The Party's Over on China's Bourses, Bus. WK., Nov. 15, 1999, at 280B (Because ailing state firms are fa- 
the more dynamic non-state sector thus are those most starved of capital because, under the current system, capital is not allocated to the most economically efficient user.

Indeed, only a few private companies have received CSRC approval to list on either the Shanghai or Shenzhen stock exchanges ${ }^{197}$ with many others, such as China's largest privately owned information technology firms-the Stone Group_-planning for a stock market listing within the next few years. ${ }^{198}$ Only in mid-1999 did serious discussion take place about allowing non-state companies, such as collectives and private companies, to list, at least on the foreign currency " $\mathrm{B}$ " share index to "enable them to raise funds via foreign portfolio investment, with foreign direct investment declining ... and bank lending very much concentrated in the state-owned sector." ${ }^{199}$ As a result, many private

vored for listing to raise capital for the government, "markets are awash in companies stuck with inefficient management and excess inventories and workers.").

197. See Rowan Callick, Yuan for the Money, Zhu for the Show, Australian Fin. Rev., Aug. 3, 1999, at 14 ("Only about 30 listed companies are privately owned."); Mark O'Neill, Eager Mainland Firms Await CSRC Approval, S. CHINA MoRNING POST, July 2, 1999, at 3, available in LEXIS, News Library, SCHINA File; Peter Wonacott, China's Securities Law Criticized for Failing to Empower Holders, ASIAN WALL ST. J., Jan. 8, 1999, at 24 ("Only a handful of the 827 companies listed in China are considered private."). But see China to Allow Privately Owned Companies to be Listed on Stock Market, CHINAONLINE, Nov. 16, 1998, available in LEXIS, News Library ("Under China's revision to its securities law, a company's ownership will no longer be a criterion in selecting companies to be listed on the exchanges."); Lu Ning, Counting on the Private Sector in a Socialist Market Economy, Bus. TIMES (Singapore), Feb. 4, 1999, at 6 (with the new securities law, which came into effect on July 1, 1999, "private businesses, originally banned from listing on China's stock exchanges, are now allowed to do that."). In practice, however, "few investors believe the government will do anything to jeopardize the dominant position of the state sector." Shanghai Shares Close Morning Higher Amid Institutional Buying, AFX EUR. FOCUS, Jan. 5, 2000, available in LEXIS, News Library. The government "may say that private companies will have the same access to the stock market, but if a private firm really asked for a listing, it would probably still have to fulfill all kinds of extra conditions and procedures." Id. (quoting unnamed analyst). In other words, the prevailing view among investors is that the practice of discriminating against private companies remains, despite laws to the contrary. See Justin Doebele, Chinese Capitalism Gets a Face, ForBES, Nov. 29, 1999, at 175.

198. See China's Biggest Private IT Company to Seek Listing, ChINA BUS. INFO. Network, July 8 , 1999, available in LEXIS, News Library. After years of being squeezed out of the credit market by the government's state banks and the securities markets, private companies, or at least those that are in the high-technology sphere, are to be granted priority in listing on the stock markets. See Kynge, Beijing Fillips, supra note 194, at 7.

199. This Week in Asia: 5 July 1999, MACQUARIE BANK THIS WEEK IN ASIA, available in Quest Economics Database; see also China: Bourses Decline as Correction Happens, CHINA DAILY, June 4, 1999, available in LEXIS, News Library; Winston Yau, SAR Investors Seek Better Transparency and Efficiency, S. CHINA MORNING POST, July 26, 1999, at 3, available in LEXIS, News Library, SCHINA File. The removal of restrictions would also allow foreign-funded companies to list on China's stock exchanges and issue "B" shares. See Christine Chan, Beijing Prepares Steps for Boost to B-Shares Market, S. CHINA MORNING POST, June 17, 1999, at 4, available in LEXIS, News Library, SCHINA File.

"A" shares, traded on both the Shanghai and Shenzhen exchanges, are available only to Chinese citizens and are quoted in renminbi. "B" shares, which represent identical ownership rights as "A" shares, are available only to holders of foreign passports and are quoted in U.S. dollars in Shanghai and Hong Kong dollars in Shenzhen. The B share market is less than one-fortieth the size of the A share market and generally attracts fewer companies. See Simon Davies \& James Harding, How Foreigners Are Hamstrung: China Dealing Restrictions Slash Opportunities, FIN. TIMES, Jan. 10, 1998, at 2. Although both A and B shares may be issued and listed by the same mainland Chinese company, pricing for the A shares is much higher than that for the B shares because A shares have outperformed B shares, possibly because companies that issue B shares are subject to international accounting rules, and B shares profits may be more realistic than those claimed by A share companies that are subject to 
companies, starved of capital needed for expansion, have searched for other, often more circuitous, ways to finance themselves, for example, by applying to list on Hong Kong's Growth Enterprise Market ("GEM"), a secondary market aimed at small and mid-size high-tech companies that opened in $2000{ }^{200}$ Even then, however, "'[h]igh-technology mainland firms that meet the requirements for listing must [still] obtain an 'exit approval permit' before listing there" ${ }^{201}-\mathrm{a}$ requirement that is supposed, as a mainland Chinese official put it, to "prevent 'a flood of refugee companies' into the Hong Kong market." ${ }^{202}$ In other instances, private companies on mainland China have had to circumvent the prohibition against listing by non-state companies by buying shares of companies that are already listed. ${ }^{203}$ After years of seeking permission to list on the Shanghai and Shenzhen stock exchanges, the Clever Software Company, a private Beijing company and one of the largest developers of education software in China, decided to become a principal shareholder in the already-listed Acheng Iron and Steel Company by buying twenty-eight percent of its shares, thereby gaining access to the stock exchanges. ${ }^{204}$

less stringent Chinese accounting standards. The B shares market has thus been sluggish, which explains why the government may need to take innovative measures such as those described in the text to increase its appeal. See id.

200. GEM got its official start in early 2000, to raise capital for high-technology companies. See India: Price Tag On New Rule on Selective Disclosure, BUS. LINE, Aug. 27, 2000, available in 2000WL 2494924; Angela Mackay, GEM Falters As Stocks Are Hit, SunDAY BuS., June 11, 2000, at 17. The general sentiment in mainland China is that " $[\mathrm{u}]$ nder the principle of one country, two systems, Hong Kong has the right to set up such a market and its stock exchange the right to control it." O'Neill, $s u$ pra note 197, at 3. See also Sheri Prasso, A Bourse of Their Own, Bus. WK., Aug. 30, 1999, at 26. Hong Kong's GEM, a Nasdaq-style market "designed specifically for companies without proven track records, will enable them to finance growth and offer venture capitalists an exit route when it's time to cash out." $I d$. at 26. Indeed, under the listing requirements for GEM, a company must be in operation for at least two years but does not necessarily have to demonstrate profitability. Compare this to listing under the Stock Exchange of Hong Kong, which requires a company to show that it has been in business for more than three years and has earned more than $\$ 6.5$ million in profits.

201. O'Neill, supra note 197, at 3 (quoting an unnamed CSRC official).

202. Id. The CSRC's chief adviser, Anthony Neoh, rejected a proposal to allow private mainland companies to list on GEM merely upon notification to the CSRC of their intention to list overseas. See Hui Yuk-Min, Listing Hopefuls Bypass Regulator, S. CHINA MoRning Post, July 1, 1999, at 4, available in LEXIS, News Library, SCHINA File (discussing how private mainland companies plan to restructure themselves into foreign companies in order to bypass this requirement). However, the CSRC later assured that it would not place any quota on the number of companies allowed listing in Hong Kong, and would "streamline the approval process for mainland listings in Hong Kong to support GEM's development." China to Support Mainland Listings on Hong Kong's GEM, AFX-ASIA, Oct. 14, 1999, available in LEXIS, News Library. Mainland private companies, however, had hoped "that the Hong Kong exchange alone could judge which firms could list, with an obligation to inform the CRSC but without giving it veto power." Mark O'Neill, GEM Rush Underlines Private-sector Plight, S. ChInA Morning POST, Nov. 1, 1999, at 4, available in LEXIS, News Library, SCHINA File. Interestingly, in the middle of 2000, the CSRC announced that China planned to launch its own mainland GEM "to help high-tech startups and private firms raise money." Chinese Plan Stock Market for HighTechs, CHATTANOOGA TiMES, July 25, 2000, at C6.

203. See Chinese Private Enterprises Sweep Up Listed Firms, supra note 195.

204. See id.; see also Callick, supra note 197, at 14. According to research conducted by Shenzhen Dapeng Securities Ltd., 15 private enterprises became main shareholders of listed firms in 1998, compared to seven in 1997, and a much smaller number before that. See Callick, supra note 197; O'Neill, supra note 195, at 3 (explaining that private firms unable to list have resorted to controlling listed firms through takeovers). 
Like private mainland companies, foreign firms, even blue chips whose listings would bring the stock exchanges prestige, face similar obstacles in their attempts to list on the Chinese stock exchange. In 1994, after years of negotiations, the German car manufacturer Daimler-Benz confirmed its plans, which later proved to be futile, to become the first foreign company to list on the Shanghai Stock Exchange. ${ }^{205}$ Unilever has been restructuring its mainland operations to secure permission to list on either of the two Chinese exchanges, although it is generally believed that the Chinese government remains wary of allowing foreign companies access to its domestic securities market. ${ }^{206}$ Because one of the primary objectives of the stock market is to provide cash for the constantly cash-starved state sector, it is not surprising that China is reluctant to allow non-state companies, whether domestic or foreign, the right to access Chinese domestic capital, which the government believes should be reserved for more state-centered strategic objectives. ${ }^{207}$ As a result, the government's reaction to the inability of the B shares market to attract as much foreign exchange as originally contemplated ${ }^{208}$ was not to improve the B shares market, ${ }^{209}$ which would benefit B shareholders. Rather, the government chose to increase its access to foreign markets and foreign currency by listing Chinese state enterprises on the stock exchanges of Hong Kong and New York, ${ }^{210}$ which raise foreign capital for the listed state firms.

205. See Foo Choy Peng, Play the Waiting Game While Seeking Mainland Listing, S. CHINA MORNING POST, May 14, 1999, at 4, available in LEXIS, News Library, SCHINA File; Christine Chan, Mainland Stock Markets Fear an Exodus of Funds, S. CHINA MoRning POst, Feb. 1, 1994, at 7, available in LEXIS, News Library, SCHINA File.

206. See Peng, supra note 205, at 7. As of October 2000 when this article was prepared for publication, Unilever was still not listed on China's stock exchanges. See Stock, XINHUA ECON. NEWS SERV., Sept. 5, 2000, available in LEXIS, News Library.

207. See Chan, supra note 205, at 7; see also Stock, supra note 206 (discussing worries over allowing foreign companies to list on Chinese exchanges "because when the capital is limited, high-quality foreign-funded enterprises will divert large amounts of funds, challenging Chinese enterprises in raising capital").

208. See supra note 199 and infra note 209.

209. As noted, it is only recently that the government announced plans to allow private companies the right to list on the $\mathrm{B}$ shares market in an effort to increase the number of listings, which the government hopes would in turn make the B shares market more attractive to investors on the global market. See Winston Yau, SAR Investors Seek Better Transparency and Efficiency, S. CHINA MORNING POST, July 26, 1999, at 3, available in LEXIS, News Library, SCHINA File; see also supra note 199 and accompanying text. For years, as compared to the A shares market, the B shares market has been sluggish, resulting in a troubling discrepancy in valuation between the two markets as A shares trade at a higher value than B shares of the same company. This discrepancy exists because Chinese investors with an excess of yuan, faced with a dearth of domestic investment possibilities, are eager to buy up almost any domestically issued financial instruments. By contrast, foreign investors, who have a much broader investment opportunity, are less willing to put up with the erratic and murky Chinese securities market and thus less eager to buy up B shares issued by Chinese firms. See Inefficient Markets?, ECONOMIST, July 31, 1993, at 70. To make the B shares market more attractive and more liquid, it has been suggested over the years, without much success, that Chinese investors holding foreign currency be allowed to buy B shares, or even that the A shares and B shares markets be merged. See Christine Chan, Calls Growing to End China's Share Classes, S. CHINA MORNING POST, Dec. 3, 1993, at 1, available in LEXIS, News Library, SCHINA File.

210. In 1992, China released a list of nine companies selected to be among the first mainland-based companies to seek direct listing in Hong Kong, and in 1993, earmarked an additional 20 companies for international listing. See Julia Sze, The Allure of B Shares, CHINA Bus. REV., Jan.-Feb. 1993, at 42, 48. 
State dominance of the securities market has resulted in severe distortions in fundamental ways. The fundraising functions mandated by the government have overwhelmed other basic governance objectives, such as market transparency and liquidity, as well as managerial accountability and shareholder's rights. ${ }^{211}$ The case of Ma'anshan Iron and Steel Company ("Magang"), one of the larger, flagship state firms that qualified for listing on the Hong Kong stock exchange in $1993,{ }^{212}$ proves this point. The company was divided into two parts: one a state-owned holding company, Magang Holding, into which all the company's less profitable mining operations, its housing agencies, healthcare facilities, and schools were transferred, and the other a public stock company, Magang Steel, which holds all of the profitable iron and steel production units. Before the shares were offered to the public, Magang Holding was given a $62.5 \%$ ownership stake, thus allowing the holding company, as the representative of the state, to retain a controlling share block. ${ }^{213}$

Within a year of its Hong Kong debut in which it raised $\$ 505$ million, ${ }^{214} \mathrm{Ma}-$ gang exhibited many of the pathologies typical of large state enterprises, such as financial irregularities and increasing short-term debt, including taxes owed to the state. Serious breaches of corporate formalities allowed the company to present an inaccurate financial picture to investors. Through much of 1994, Magang Steel paid out dividends to its individual investors but not to Magang Holding. The dividend withholdings were merely deemed interest-free loans, and as dividends were being paid out on less than forty percent of outstanding shares, this allowed Magang Steel artificially to inflate its declared dividends and, at the same time, artificially to deflate its costs by reneging on its various contractual obligations to Magang Holding.

Despite being a controlling shareholder in the stock company, Magang Holding could not enforce its rights because it could not act as a true owner. Both the general manager and the party secretary of Magang Holding were appointed chairman and vice chairman of the board of Magang Steel, respectively,

211. The CSRC has received numerous complaints about company compliance with basic regulations. See Christine Chan, Quality of Listed Stocks Must Be Raised, S. CHINA MoRnING POST, Mar. 22, 1994, at 14, available in LEXIS, News Library, SCHINA File. For example, according to officials at the privatized Shanghai Vacuum Electron Device Company, although the Shanghai municipal government owns $75 \%$ of its stock, the firm has never been paid for the shares, but it must nonetheless issue dividends on them. See Paul Schroeder, Rebuilding China's Securities Markets, CHINA Bus. REV., MayJune 1991, at 20,21. Shareholder complaints often center on a company's failure to comply with its own original plans for share issue proceeds and to keep shareholders informed. See Lui Weiling, China: Wariness Reigns Among Stock Investors, BUS. WK. (China Daily Supp.), Jan. 30, 1994, available in LEXIS, World Library, TXTLNE file.

In 1995, after Tsingtao Brewery raised U.S. $\$ 190$ million in an initial public offering, it was discovered that company managers had taken U.S. $\$ 71.2$ million that had been earmarked for expansion projects and loaned it to other firms. See Craig S. Smith, Chinese Brewer's Stock is Suspended, WALL ST. J., Apr. 12, 1995, at A11.

212. See The Rise of the Red Chip, EUROMONEY: InT'L INVESTORS' GUIDE TO ASIAN ISSUERs \& CAPITAL MARKETS (Supp.), Dec. 1993, at 23, 23.

213. See STEINFELD, supra note 59, at 146. My discussion of the Magang study is drawn from id. at 124-64.

214. See The Rise of the Red Chip, supra note 212, at 23. 
so that the top two people at the holding company also shared the top two positions on the stock company's board. Even so, they had no right to appoint or fire their subordinates in the stock company-such as the general managerbecause those positions could be filled only by provincial government appointees. ${ }^{215}$ Thus, although it is a clearly defined majority owner, Magang Holding was not granted the kind of control over appointments and removals to allow it to perform its monitoring and enforcement functions over Magang Steel's management. ${ }^{216}$

Nor could it sue Magang Steel, according to Magang Holding officials, because of loopholes in China's corporate code. ${ }^{217}$ Indeed, in a recent court case brought for the first time by an individual shareholder against a Chinese firm for damages caused by the firm's false disclosure, the shareholder sued the company for losses sustained as a result of the company's inflated earnings, figures declared when it sought to list on the Shanghai stock exchange. The chairman and chief financial officer of the company had been sentenced to jail for fraud. The court, however, declined to hear the suit brought by the individual investor, holding that it was the purview of the CSRC, not individual shareholders, to address illegal acts. ${ }^{218}$ In fact, the new national law on securities, effective July 1, 1999, does not explicitly create a private cause of action for shareholders. While Chapter XI, entitled "Legal Responsibilities," contains many provisions setting forth various administrative penalties for violations of the securities law, including confiscation by the state of illegal earnings, fines, revocations of business licenses, and even criminal liability, it fails to provide

215. The politicization behind China's system of managerial appointment remains a problem. See, e.g., Anthony Neoh, Rethinking Asia: China Strengthens Its Markets, FAR E. ECON. REV., Jan. 14, 1999, at 69, available in WESTLAW, News Library ("Most listed companies are managed by former government officials who are still learning the skills needed to run profitable businesses."); China Regulator Sets New Trade Rules for Money-Losing Companies, Dow JONEs Bus. NEws, July 5, 1999 ("More than $90 \%$ of listed companies are controlled by the government, and most company managers are appointed by state-run parent companies.").

216. See, e.g., Gordon Chang, Revitalizing China's State-Owned Enterprises, Dow JONES NEWs SERV., July 6, 1999 (Even though there are about 900 state-owned enterprises listed on the various stock exchanges, "partial privatization has had limited benefits. Stock listings have raised vast amounts of money in public markets ... [but] [m] any listed [state-owned enterprises] are still struggling because management has not improved.").

217. The legal representative of a shareholding company is the chairman of the board. The legal representative of a state-owned enterprise is its general manager. In Magang's case, the general manager of Magang Holding is the same person as the chairman of the board of Magang Steel. Under Chinese law, the plaintiff would be the same as the defendant, and the suit would be unable to go forward. See STEINFElD, supra note 59, at 156; see also Henny Sender, Shareholder Rights Case Points Up CSRC's Power, ASIAN WALL ST. J., July 23, 1999, at 13, available in WESTLAW, News Library (describing case in which a Chinese court declined to hear a suit brought by a plaintiff shareholder against a Shanghai-listed company for false disclosure; the court held instead that it was the CSRC's sole purview to address illegal acts).

218. See Henny Sender, In Hong Kong: China's Court Ruling Shows Market Reforms' Slow Pace, AsIAN WALl ST. J., July 23, 1999, at 13 (stating that the new securities law passed in July 1999 does not grant an explicit individual cause of action and even suggests that any compensation for losses resulting from false disclosures, for example, is owed to the government); Chang, supra note 216. 
for civil remedies, such as derivative suits, that would allow shareholders to sue the company and its directors and officers. ${ }^{219}$

Equally important, Chinese norms and customs governing the interaction between the holding company and the stock company also discourage the initiation of such a suit, especially because of the stock company's high-profile status as a national experiment in corporatization and public offerings. As one of the first and largest state enterprises to issue stock internationally, the value of Magang Steel's shares on the stock markets had to be maintained. Thus, Magang Steel was allowed to renege on dividend and other contractual obligations to its parent holding company to meet its own expansion and modernization costs. Magang Holding, on the other hand, had to continue meeting its own obligations, such as debt related to its mining operations and taxes owed due to various pre-arranged tax submission targets by borrowing from state banks, just as it did prior to the implementation of shareholding. And so continued the cycle of soft budget constraints and inter-firm debt.

Thus, even after privatization, the stock company exhibited much of its preprivatization behavioral pattern. Released from the dictates of the plan, yet unaccountable to and unmonitored by any true owner, it seized upon new opportunities to capture rents. Agency problems persist because of non-existent or ineffective monitoring, whether through corporate governance mechanisms or through legal machineries that allow shareholder rights to be enforced. Inter-firm debt, distorted financial flows, and soft budget constraints persist due to the complete absence of or lapses in corporate formalities among affiliated firms. Without substantial changes in the firm's institutional environment and unless critical governance issues are implemented, ownership restructuring merely results in the duplication of preexisting distortions, even though privatization has been initiated with the full intention of replacing the multiplicity of vertical and horizontal state agencies claiming authority over the firm with a clearer system of shareholding. Therefore, introducing private owners into an environment in which the state bureaucracy, including its banking and legal system, continues to act in politicized and noncommercial ways will almost certainly guarantee failure in most respects, except of course, in the most shortterm of objectives-capital infusion from the domestic and foreign shareholding public.

To further ensure continued political control over and domination of the stock markets, Chinese law also classifies shares by reference to the status of the shareholders: state shares, legal person shares, and individual shares. State shares are purchased with state assets by governmental departments and usually constitute fifty percent or more of all issued shares, ${ }^{220}$ which means that the state

219. See Securities Law of the People's Republic of China, adopted by the Sixth Session of the Ninth National People's Congress Standing Committee, Dec. 29, 1998 (effective July 1, 1999) (visited Oct. 11, 2000) <http://www.chinaonline.com/refer/legal/laws_regs/important_documents.asp >. Civil remedies, however, might be inferred from Article 207, which provides that in the event a violator of the securities law cannot pay both administrative and civil fines, civil compensation shall be paid first.

220. See Qian, supra note 110, at 87; Fang, supra note 179, at 201 (noting that "[u]ntil August 1993, 
is a majority shareholder in most instances. ${ }^{221}$ Legal person shares are owned by entities such as companies and institutions-usually other state enterprises. ${ }^{222}$ Individual shares are held by employees or individual investors from the general public. ${ }^{223}$ Only individual shares of listed companies can be traded on the stock exchanges. ${ }^{224}$ State shares and legal person shares, on the other hand, are nontransferable, thus ensuring that the state and its agencies retain their respective dominance. ${ }^{225}$ For example, in 1996, when the Shanghai-listed Beijing Light Bus sold a twenty-five percent stake in non-transferable legal person shares to two Japanese companies, Isuzu Motors and Itochu, the government allowed the transaction only reluctantly and promptly decreed that no similar transactions would be permitted in the future. ${ }^{226}$ Similarly, when the board of directors of Harbin Pharmaceutical, a Shanghai-listed company, approved a transfer of fiftytwo million state shares to individual shareholders in 1993, the CSRC allowed the transfer only after it issued a stern warning and only after it determined that

out of all the 15.47 billion (face value) shares listed on the Shanghai Exchange by 70 companies, $68 \%$ were State shares, $12 \%$ were legal person shares, $10 \%$ were transferable individual shares ...").

221. See Karby Leggett, China to Put New Stress on Quality in Deciding Which Firms to List, AsIAN WALL ST. J., Jan. 21, 1999, at 22; Neoh, supra note 215, at 69; Zaloom \& Hongchuan, supra note 190, at 26, 27; Callick, supra note 197, at 14.

222. See Fang, supra note 179, at 202-03.

223. See supra notes 184, 185, 199 (A shares and B shares are individual shares, but A shares, denominated in local currency, are held by individual domestic investors and B shares, denominated in United States or Hong Kong dollars, are held by foreign investors.); see also Fang, supra note 179, at 210.

224. See supra note 184 and sources cited therein. To further ensure state domination, an individual may own no more than $0.5 \%$ of a company's total outstanding shares. See Opinion, supra note 182 , arts. 10, 12, 13, 24; see also Bersani, supra note 2, at 314-15 n.44. Shanghai exchange regulations also contain the same limitation. See Qian, supra note 110, at 87 n.102.

225. See Fang, supra note 179, at 211; Mark O’Neill, Securities: Doubts Grow About Command-Style Controls, S. CHINA MoRning POST, Nov. 12, 1998, at 2, available in LEXIS, News Library, SCHINA File; Foo Choy Peng \& Christine Chan, Deng's Inheritance Booms, S. ChINA MoRnING Post, Nov. 12, 1998, at 1, available in LEXIS, News Library, SCHINA File; Zaloom \& Hongchuan, supra note 190, at 27; This Week in Asia, supra note 199, at 1; see also supra note 184. The government is investigating the possibility of allowing the sale of state shares to state-owned investment companies. See Shanghai Morning Close, AFX AsIA, Aug. 14, 2000, available in LEXIS, News Library. To do so, it may need to inject capital into the investment firms to help them buy state shares, presumably because the government wants "to reduce the proportion of listed companies' state shares before the country enters the World Trade Organization." Id. (quoting a securities dealer); see also China Discussing Detailed Measures for Cut in State Ownership of Listed Firms, AFX ASIA, Oct. 21, 1999, available in LEXIS, News Library (reporting on the initiatives in the Communist Party Central Committee "to allow a reduction in listed companies' state shares" without undermining the stability of the stock market); Kit Marlow, $A$ Week of Praise and Promises for China's SOE Reformers, CHINA OnLINE (Aug. 6, 1999) (visited Dec. 7, 2000) <http://www.chinaonline.com/issues/econ_news/newsarchive/secure/1999/august/c9080530.asp> (examining the partial privatization of state firms through the sale and trading of state shares held in Handan Iron and Steel, Shanghai Petrochemcial, Shenergy, and Jilin Chemical Fibre, companies included in the first batch of partial privatization); Shanghai A Shares Close Flat Amid Caution, AFX EUR. FOCUS, June 28, 2000, available in LEXIS, News Library (discussing the government's plan to begin allowing the trading of state shares); Shanghai Stocks Rise 3.7 Percent As Insurance Money May Enter Market, AGENCE FRANCE PRESSE, Oct. 27, 1999, available in LEXIS, News Library (reporting that the CSRC may allow two listed companies' state shares to begin trading).

226. See Peng, supra note 205, at 4. 
the company had recognized its mistake. ${ }^{227}$ Given the fact that state shares comprise the majority of a company's total shares-Harbin's state shares, for example, constituted seventy-four percent of its total ${ }^{228}$ - the illiquidity of stateowned shares "makes it difficult for stock markets to exercise their function of adjusting state owned assets structurally," ${ }^{229}$ causing the market to be marked by excessive state domination. ${ }^{230}$

Despite repeated suggestions that state and legal person shares be merged with individual shares to make them tradeable ${ }^{231}$ and hence the market for trading more liquid, the government has rejected the proposal "because it has a bearing on the property rights system of state-owned assets and the business administration system." 232 When the highly entrepreneurial province of Shenzhen issued a regulation allowing state enterprises to trade their 1994 bonus shares six months after issuance, the central government promptly reversed the provincial decree. As Zhu Li, then the spokesperson for the Securities Regulatory Committee, declared, "trading in shares other than those held by individuals is banned because it involves aspects of transfer of national property rights. $" 233$

Other, more modest suggestions have not been accepted either. As far back as 1993, there were rumors that state officials might be willing to allow state enterprises to be "quasi-privatized." In that case, state holdings could decrease to twenty or even fifteen percent, ${ }^{234}$ from the current level of fifty percent or more of total issued shares. Under another proposal, state-held shares would be traded, but the state would retain the right to redeem the shares within five years. "[T]he proposal would enable state-held shares to effectively realise their value, improve a company's shareholding structure and avoid loss of stateowned property." 235 Should the state elect not to exercise its right of redemption within the allotted time period, its decision presumably would be based on the calculation that a better return could be achieved elsewhere.

As has been suggested, firms should be allowed to issue common stock $^{236}$ that is not owned by the state, and public investors should be allowed to pur-

227. See Fang, supra note 179, at 232-33, 238 n.163. Harbin had modeled its transfer scheme after the experiences of two companies on the Shanghai exchange that had transferred their state shares to their respective individual shareholders without interference from the CSRC. See id. at 237-38.

228. See Fang, supra note 179, at 232.

229. Foo Choy Peng, 5.5b Shares Planned for Mainlanders, S. ChInA MoRning Post, Jan. 20, 1994, at 4, available in LEXIS, News Library, SCHINA File.

230; see supra note 184 and sources cited therein.

231. See infra notes 234-235.

232. Peng, supra note 229, at 4 (statement by Liu Hongru, chairperson of the CSRC).

233. CSRC Puts Stopper on Shenzhen Share Plan, S. ChInA Morning Post, Mar. 5, 1994, at 4, available in LEXIS, News Library, SCHINA File.

234. See China to Cut State Holdings to 20\%, Paper Says, JAPAn ECON. Newswire, Dec. 7, 1993, available in LEXIS, Asiapc Library, JEN File.

235. Christine Chan, Calls Growing to End China's Share Classes, S. ChInA Morning Post, Dec. 3, 1993, at 1, available in LEXIS, News Library, SCHINA File.

236. Common stockholders are considered residual claimants in the corporation because their claims to income and assets of the corporation come after all other claims have been satisfied. See, e.g., 
chase a majority without the current system of restrictions, which would, in turn, enable the market for corporate control to function more effectively, thereby lowering agency costs. ${ }^{237}$ A parallel can be found in studies comparing the performance of firms in which there are residual claimants ${ }^{238}$ with those in which there are none or firms in which the residual claimants have no voting rights. "Firms without shareholders do poorly compared with other firms, and firms whose structure prevents the formation of a control bloc of shares also do relatively poorly." ${ }^{239}$ For example, mutual banks or savings and loans, where the right to vote depends on deposits and not transferable shares, show a lower level of economic performance when compared with commercial banks, in which there are transferable shares. ${ }^{240}$ This suggests that a public and liquid market for shares allows capital markets to function more effectively and enables firms to operate more efficiently. ${ }^{24}$

REVISED MODEL BUSINESS CORPORATION ACT § 6.03(c) (1984). Common stockholders have greater potential for greater returns on their investments but also lower right of priority and greater risks of loss. They are thus given control of the corporation through voting rights, that is, the right to select the board of directors. See also MiLgROM \& ROBERTS, supra note 18, at 291 (the owner of a property retains the right of residual control, that is, the right to dispose of the assets in any manner not prohibited by law or not contractually restricted, and the right to claim profits after other claimants, for example, the government, creditors, and suppliers, have been paid).

237. The active trading of shares itself creates a market mechanism to monitor the business. The market price of a share is a reflection of the underlying economic performance of the company and its management. For the share price to serve that purpose, there must be an efficient market for the trading of the shares, so that the share price reflects all available information. This is the Efficient Capital Market Hypothesis: numerous active traders reacting quickly to new information, which is immediately reflected in the price of the shares. See generally RiCHARD A. BREALEY \& STEWART C. MYERS, PRINCIPLES OF CORPORATE FINANCE 323-31 (5th ed. 1996).

238. See supra notes 18, 19 and infra notes 239-240.

239. Frank EASTERbroOK \& DANIEL Fischel, THE ECONOMIC STRUCTURE of Corporate LAW 72 (1991). Firms that have clearly identifiable residual claimants generally do better than firms with none. See also David G. Davies, The Efficiency of Public Versus Private Firms: The Case of Australia's Two Airlines, 14 J.L. \& ECON. 149 (1971). The comparison is limited to firms that operate for profit only.

240. See Maureen O'Hara, Property Rights and the Financial Firm, 24 J.L. \& ECON. 317, 319-21 (1981). In a mutual savings and loan, the depositor's position is one of holding deposits rather than owning shares, presumably to "elevate the depositor's relationship to the association from that of owner to that of depositor-creditor, thus allowing the depositor a higher claim should liquidation occur. If the depositor is a creditor, however, it is difficult to discern exactly who owns a mutual." Id. at 319. Equally significant, "[b]ecause the value of the mutual association cannot be sold in the market, increasing the association's value is not the important objective it is in the stock association." Id. at 321. By contrast, where the owners of a stock association are the stockholders, "[m]anagement is under the control of the owners ... [and] property rights are clearly defined." Id. at 320; see also Davies, supra note 239, at 149-50 (discussing the economic limitations of public ownership in that "[a] public owner is unable to sell or exchange property rights to his share of public ownership whereas a private owner may at some price either buy or sell ownership rights to private property." In turn, "if ownership is transferable, there are comparative advantage effects ...."); Eric Rasmusen, Mutual Banks and Stock Banks, 31 J.L. \& ECON. 395 (1988).

241. Assuming that there is an effective and liquid capital market, this market can be efficient and still entirely private, with its own system of private ordering and governance, in other words, without an SEC-type of oversight. See Roberta Romano, Empowering Investors: A Market Approach to Securities Regulation, 107 YALE L.J. 2359, 2373 (1998) ("[B]efore the enactment of the federal securities laws in the 1930s, public corporations voluntarily disclosed financial statements, typically under a stock exchange listing requirement, that contained substantially all of the information subsequently required under the federal laws."). Professor Romano discussed a study by George Benston that found that be- 
Chinese privatization, by contrast, has been astonishingly unconcerned by issues of market efficiency. Rather it has been characterized by one overarching concern: that the reservoir of private capital in the non-state sector be brought under the state's control to serve the state's financial needs. As I have shown above, the securities market has been designed to bring in private or foreign capital for state companies within the tightly circumscribed perimeters of state-controlled "market socialism." First, through its regulation of the listing process and the shares quota system, the government ensures that state, not private or foreign companies, have priority access to investment capital. Second, through its share classification rules, the government also ensures that private capital drawn into state firms as individual shares remains submerged under the domination of majority state and legal person shares. Finally, through transfer regulations that prohibit trading in state and legal person shares, the government further ensures that the state retains its position as the superdominant majority shareholder. With such single-minded emphasis on the market as a mere fundraising vehicle-and everything else, such as market liquidity, shareholder rights and governance mechanisms to constrain predatory behavior, whether by state or private actors, only a secondary issue-it is not surprising that state-sector reform still leaves much to be desired.

State-sector privatization has not worked because it has not been supported by the institutional framework that is necessary to make a property rights regime work. While China is now adopting a Coasian model in its effort to create property rights-based on the presumption that once property rights are created they will be allocated to the highest-valued use-it has not adopted the institutional framework necessary to minimize transaction costs and thereby facilitate the movement of resources to the highest-valued use. ${ }^{242}$ As Coase noted in his discussion of how the state could institute the necessary framework to reduce the costs of transacting,

[s]ince, by and large, people choose to perform those actions which they think will promote their own interests, the way to alter their behavior in the economic spheres is to make it in their interest to do so. The only means available to the government for doing this ... is a change in the law or its administration. The forms such changes may take are many. They may amend the rights and duties which people are allowed to

fore the passage of the federal securities laws in the 1930s, the listed companies, pursuant to requirements imposed by the private securities exchanges themselves, had already produced annual reports and other requirements except for reports of the firms' sales later mandated by federal law. Professor Benston also found that there was no significant price effect for firms affected by the new mandated disclosure-those 38\% listed on the New York Stock Exchange that had not previously reported their sales-and those firms that are not so affected-those $62 \%$ listed on the New York Stock Exchange that had already disclosed sales information prior to the federal requirement. See George J. Benston, Required Disclosure and the Stock Market: An Evaluation of the Securities Exchange Act of 1934, 63 AM. ECON. REV. 132, 144-45 (1973); George Benston, An Appraisal of the Costs and Benefits of Government-Required Disclosure: SEC and FTC Requirements, 41 LAW \& CONTEMP. PROBS. 30, 51-52 (Summer 1977).

242. For a discussion of Coase and transaction costs, see supra notes 21-23 and accompanying text. 
acquire or are deemed to possess, or they may make transactions more or less costly by altering the requirements for making a legally binding contract. ${ }^{243}$

Reforms in the institutional framework in which China's state enterprises operate are thus crucial if privatization is to result in the creation of a true property rights regime and a truly market-oriented, rather than politically controlled, market. In this respect, even a minimalist Delaware-type model of corporate governance would be highly effective in altering the behavior of owners and managers. First, basic corporate formalities to ensure that a corporation exists and acts as an entity separate and apart from its shareholders are necessary, for example, to prevent the corporation and its controlling stockholderin China, the state, in most instances - from acting as each other's alter ego, and thereby creating intermingled and muddled ownership rights, which privatization itself is supposed to have rendered transparent. As the Magang example demonstrates, privatizing does not necessarily create clearly delineated property rights. Neither the state shareholder, the investing public, nor some other state enterprise can be said to truly hold the property right in the quasiprivatized, state-owned firm, with the related rights of control and return normally associated with ownership. Second, adopting rules that permit majority ownership by non-state entities and the trading of such shares would create a more liquid market and facilitate the movement of assets to the highest-valued use. Finally, permitting shareholder suits to enforce the duty of care and the duty of loyalty would also minimize transaction costs, particularly those related to investigation and monitoring costs inherent in principal/agent problems.

State-sector privatization, in other words, is necessary but not sufficient. Unless there is a functioning market equipped with a functioning property rights regime, privatization by itself is not sufficient to induce a change in the behavior of newly privatized, state-owned enterprises. Privatization, in other words, will not necessarily create a market unless the proper institutional framework, as I have suggested above, is put in place.

\section{VI}

\section{CONCLUSION}

The discourse on transitional economies has been circumscribed by a number of incorrect assumptions about the fundamentals of economic reform and the very foundation of a functioning market economy. First, it has been widely assumed that the failure of command economies means that state ownership must be replaced by private ownership, which in turn requires immediate statesector privatization. Second, divesting the state of its assets in state firms and transferring them to private holders, it was assumed, will result in an efficient restructuring of the firms by the market itself because privatization will create

243. COASE, supra note 22, at 28; see also COASE, THE InSTITUTIONAL STRUCture OF PRODUCTION, supra note 23, at 716-18 (noting that legal institutions have an effect on transaction costs and on the nature of transactions that take place). 
the market, which will then force the newly privatized firms to act in competitive, market-oriented ways.

Those were the assumptions that guided the transitional path in Russia. China, however, has proven these assumptions wrong. In a period of twenty years, China has created and embarked on its own path of reform, one markedly different from the "Washington Consensus" 244 model of transition prescribed for and applied to Russia. It began privatizing its economy by leaving the state sector intact and by concentrating on removing barriers to entrepreneurship, allowing new firms to be created, and establishing, gradually but steadfastly, a market-oriented economy. Between 1978 and 1996, the country grew at an annual average rate of almost ten percent, mostly because of the proliferation of new firms in the new, non-state sector, established at the margin of and parallel to the old state sector. The initial preservation of state firms, in many cases, served as an anchor for the new firms and stimulated their growth. The new firms, in turn, acted as an economic and social cushion, absorbing workers from the old state sector as it went through the difficult process of restructuring.

In phase one of China's reform, the focus was on the creation of new firms. The state allowed the redeployment of resources from less productive agricultural communes to more productive household farming. With relatively little cost to and involvement of the government, the basic foundations for a marketoriented economy were instituted to facilitate the entry of new businesses. Incentives were created by allowing farmers to sell any above-quota surplus on the open market, which resulted in a spectacular increase in rural productivity and most significantly, an accumulation of private capital for investment and entrepreneurship.

As important as entry is to entrepreneurship, its inverse-exit-is crucial as well. Subject to hard budget constraints, the new firms in the non-state sector, unlike the state-owned enterprises, have no access to state credit or subsidies and must rely on their own retained earnings for their operating budgets. The purchase of inputs and the sale of outputs must be conducted within a commercially oriented framework and must be responsive to price signals from the market. Those who fail to be sufficiently competitive face the threat of bankruptcy-induced market exit. Thus, in the non-state economy at least, economic actors are granted autonomy but are also subject to restrictions-a credible threat of bankruptcy and the constraints of a hard budget. Privatization-defined here as the creation of new firms and the establishment of a separate market economy-has resulted in an impressive rise in economic growth and a concomitant increase in the living standards of the majority of the country's citizens.

In stark contrast to its vibrant non-state sector, however, China's state sector is on the verge of an economic crisis so severe that it threatens to drag down

244. Stiglitz, supra note 14 , at 4. 
the country's entire economy along with it. Restricted by the mantra of "market socialism," the reformers first attempted to pursue state-sector reform by means other than the transformation of the ownership base of state firms, thus sidestepping inflammatory labels such as privatization in favor of more pragmatic strategies such as decentralization and incentivization. Phase two of China's reform emphasized the separation of the state's ownership from administration of an enterprise, so that management rights could be transferred downward to the level of the firm, and managerial autonomy could be translated into increased firm productivity.

While that strategy theoretically should have yielded positive results, it failed to do so because, as I have argued throughout this article, merely separating the firm from the state and granting the firm more rights, freedom, and autonomy does not, by itself, produce positive behavior. While liberation from the strictures of the plan and the separation of the firm from the state are positive steps, decentralization in China broke up the command economy and created a complex layering of governmental agencies at various levels of vertical and horizontal chains of authority, all eager to exert extractive authority over firm assets but none willing to be held responsible for the firm's financial being. Problems at the state level resulting from decentralization created similar problems at the firm level. Decentralization allowed managers more autonomy, but without an internal governance regime to enable owners to monitor their agents, and without a corresponding external regime to discipline managers through the imposition of hard budget constraints and a credible bankruptcy threat, autonomy without governance or accountability has not produced market actors who act in asset-enhancing ways.

As a result, state firms remain stubbornly nonmarket in their orientation. In its current phase of reform, China finally is embarking on what it has deferred for years: conversion of state firms into shareholding companies whose shares trade publicly on domestic and foreign stock markets. Chinese state-sector privatization, however, has been a disappointment in many respects. First, the government has, from the beginning, pursued it not to turn state-owned enterprises into privately owned enterprises, but to bring the huge accumulation of inert private capital into the state's orbit by enticing the Chinese public to use private savings to purchase shares in state-dominant firms. Second, the government accordingly has used the securities market for the primary, if not sole, purpose of fundraising, with only lip service ostensibly paid to ancillary matters such as shareholder rights, financial disclosure, and market liquidity. Third, in its effort to use the securities market to salvage failing state enterprises, the government also has limited listing to state, not private companies, thereby preventing critical capital resources from flowing toward investments that might generate the greatest returns. And fourth, to maintain the state's continuing domination of supposedly "privatized" companies, even at the expense of market liquidity, shares are divided into state, legal person, and individual shares, with state shares constituting approximately fifty percent or more of total issued shares, none of which can be traded. These continuing attempts by the gov- 
ernment to constrain the securities market within ideologically acceptable perimeters-even as it goes about the business of reforming the ownership structure of state enterprises-have resulted in serious and systemic market distortions.

Even more disturbing than the flawed implementation of privatization, however, is the fact that China, which has avoided many of the economic difficulties that came from immediate state-sector privatization, is now duplicating the same flawed assumptions that characterized Russia's reform process: a singular preoccupation with privatization, that is, nominal ownership issues, at the expense of everything else needed to make ownership work. Even though the government refuses to speak the outward language of privatization, preferring instead to "securitize" or "corporatize," it has been adopting the very underlying logic of the "Washington Consensus" of which it is so publicly critical. Too easily, it has been assumed that privatization should take place before the institution of a regulatory environment or a market framework because privatization will set into motion the market itself, which will, in turn, spawn competitive, market-oriented behavior. Yet, as has been amply documented, complex organizations with dispersed owners are inevitably characterized by the separation of ownership and control. Hence, a complex combination of issues inevitably arises, such as those related to principals and agents, informational asymmetries, and transaction costs.

In other words, unless China's privatization discourse is expanded to include a serious discussion of constraints, rather than just freedom and autonomy, the institution of clearly defined private property rights will not, by itself, cause a fundamental transformation in the economic behavior of privatized firms. The problem will thus remain: privatized firms that operate within an institutional environment characterized by the absence of both property rights and of a truly functional market. 